\title{
Rift processes and crustal structure of the Amundsen Sea Embayment, West Antarctica, from 3D potential field modelling
}

\author{
Thomas Kalberg $^{1} \cdot$ Karsten Gohl $^{1} \cdot$ Graeme Eagles $^{1} \cdot$ Cornelia Spiegel $^{2}$
}

Received: 25 April 2015/Accepted: 9 September 2015

(C) Springer Science+Business Media Dordrecht 2015

\begin{abstract}
The Amundsen Sea Embayment of West Antarctica is of particular interest as it provides critical geological boundary conditions in better understanding the dynamic behavior of the West Antarctic Ice Sheet, which is undergoing rapid ice loss in the Amundsen Sea sector. One of the highly debated hypothesis is whether this region has been affected by the West Antarctic Rift System, which is one of the largest in the world and the dominating tectonic feature in West Antarctica. Previous geophysical studies suggested an eastward continuation of this rift system into the Amundsen Sea Embayment. This geophysical study of the Amundsen Sea Embayment presents a compilation of data collected during two RV Polarstern expeditions in the Amundsen Sea Embayment of West Antarctica in 2006 and 2010. Bathymetry and satellite-derived gravity data of the Amundsen Sea Embayment complete the dataset. Our 3-D gravity and magnetic models of the lithospheric architecture and development of this Pacific margin improve previous interpretations from 2-D models of the region. The crust-mantle boundary beneath the continental rise and shelf is between 14 and $29 \mathrm{~km}$ deep. The imaged basement structure can be related to rift basins within the Amundsen Sea Embayment, some of which can be interpreted as products of the Cretaceous rift and break-up phase and some as products of later propagation of the West Antarctic Rift System into the region. An estimate of the flexural
\end{abstract}

Thomas Kalberg

thomas_kalberg@web.de

1 Department of Geosciences, Alfred-Wegener-Institut Helmholtz-Zentrum für Polar- und Meeresforschung, Am Alten Hafen 26, 27568 Bremerhaven, Germany

2 Department of Geosciences, University of Bremen, Bremen, Germany rigidity of the lithosphere reveals a thin elastic thickness in the eastern embayment which increases towards the west. The results are comparable to estimates in other rift systems such as the Basin and Range province or the East African Rift. Based on these results, we infer an arm of the West Antarctic Rift System is superposed on a distributed Cretaceous rift province in the Amundsen Sea Embayment. Finally, the embayment was affected by magmatism from discrete sources along the Pacific margin of West Antarctica in the Cenozoic.

Keywords Potential field modelling - Tectonics of West Antarctica · West Antarctic Rift System · Crustal architecture of the Amundsen Sea Embayment

\section{Introduction}

Knowledge of the present architecture of the Pacific margin of West Antarctica is essential for improved plate kinematic and tectonic reconstructions of the Amundsen Sea Embayment (ASE) (Fig. 1). The embayment experienced processes that formed the southern Pacific starting with the inferred collision of the Hikurangi Plateau with the Gondwana subduction margin at approximately 110-100 Ma (Davy and Wood 1994; Mortimer et al. 2006) and continuing until the evolution of the West Antarctic Rift System (WARS).

Additionally, as tectonic processes can influence the variation of environmental conditions (Hay 1996), understanding the region's tectonic history may help constrain models and concepts for Cenozoic global cooling and Antarctic glaciation (De Conto and Pollard 2003; Coxall et al. 2005). For example, there is an increasing interest in the geomorphological evolution of the ASE and the controls it 


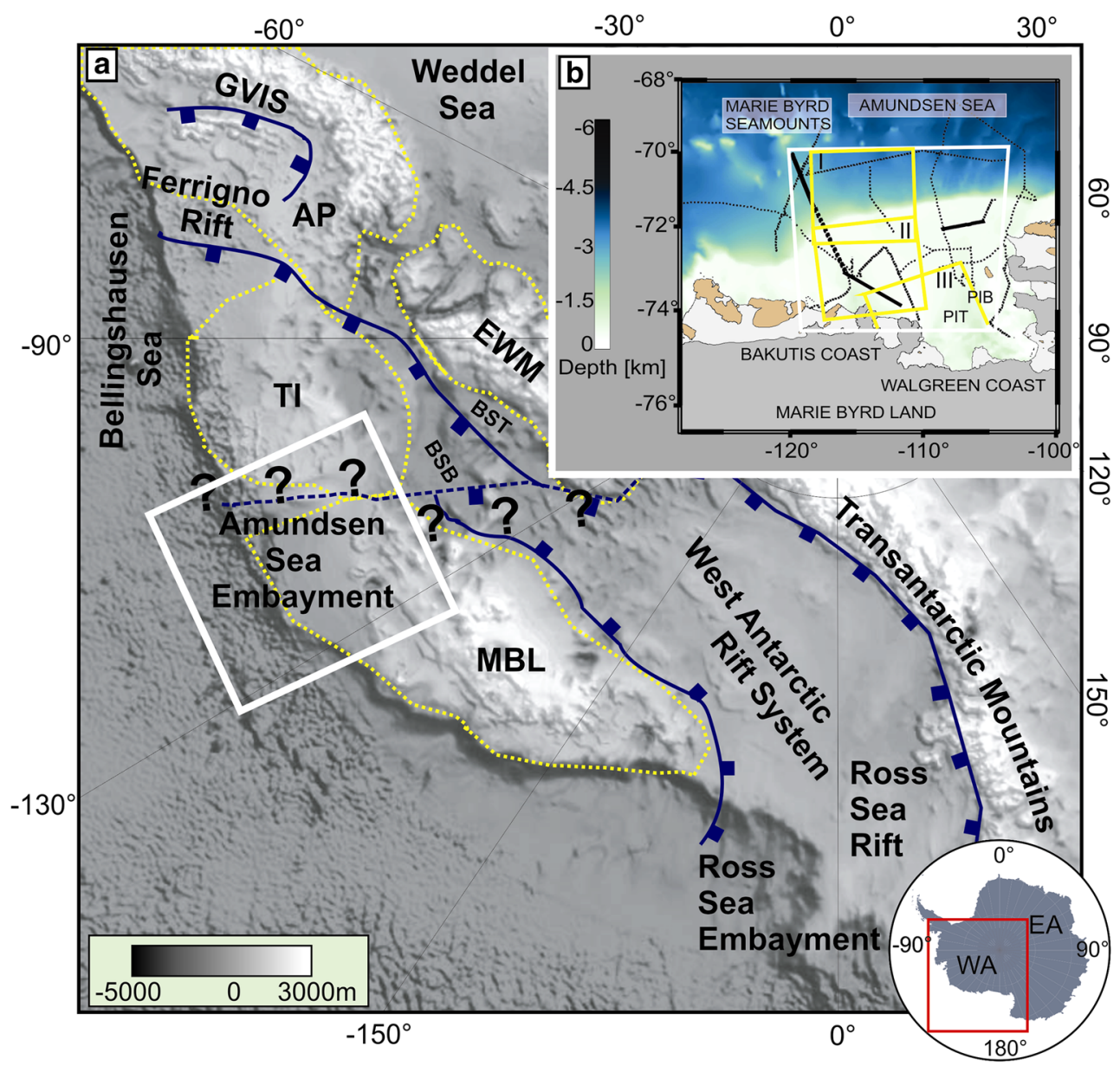

Fig. 1 a Topographic map of West Antarctica showing the regional setting derived from BEDMAP2 (Fretwell et al. 2013). Tectonic blocks (Dalziel and Elliot 1982) are marked in yellow-dotted areas: EWM Ellsworth-Whitmore Mountains, TI Thurston Island, AP Antarctic Peninsula, MBL Marie Byrd Land. Rift structures such as the West Antarctic Rift System, Ferrigno Rift (FR) and George IV Sound (GIVS) are indicated with blue lines. The dotted blue line shows a possible extension of the West Antarctic Rift System branch into the Amundsen Sea Embayment. b Overview bathymetric map of

exerted on the dynamics of the West Antarctic Ice Sheet (WAIS) (e.g. Bell et al. 1998; Studinger 2001; Dalziel and Elliot 1982). In addition, detailed knowledge of the lithospheric development may provide constraints on key geological parameters to estimate geophysical proxies such as geothermal heat flux (Shapiro and Ritzwoller 2004).

The influence of plate tectonic processes on the evolution of the cryosphere has been studied in other regions of Antarctica such as the Scotia Sea, just north of the Antarctic Peninsula (Lawver et al. 2011; Eagles and Jokat 2014). However, knowledge of the tectonic development and continental lithospheric structure in West Antarctica is based mostly on geophysical studies in the Ross Sea (Cooper et al. 1991; Trey et al. 1999; Luyendyk et al. 2001, 2003), Marie Byrd Land (LeMasurier and Landis 1996; the Amundsen Sea Embayment after Nitsche et al. (2007) showing the locations of three seismic refraction profiles (thick black lines) (Kalberg and Gohl. 2014) and seismic reflection profiles (thin dotted black lines). Yellow frames show the areas used for the spectral analysis of the magnetic and gravity anomaly data. The white frame shows the area within which our potential field data are modelled. PIB is Pine Island Bay, PIT is Pine Island Trough, BST Bentley Subglacial Trench, BSB Bentley Subglacial Basin

Winberry and Anandakrishnan 2004; LeMasurier 2008) and the Pine Island Glacier region (Jordan et al. 2010). These regions are characterized by thinned continental crust with an average thickness of 21-25 km. Numerous fault-bounded basins in the Ross Sea sector comprise the well-known WARS. Further east, a crustal thickness of $21 \mathrm{~km}$ under the Bentley Subglacial Trench suggests intra-continental extension there too (Winberry and Anandakrishnan 2004).

Recent studies of the ASE presented by Weigelt et al. (2009), Gohl et al. (2007, 2013a, b), Wobbe et al. (2012) and Kalberg and Gohl (2014) reveal the embayment to be underlain by multi-staged rifted, extremely stretched and magmatically-underplated continental crust which is overprinted by several tectonic lineaments. The data have been interpreted to indicate a set of rift basins that formed 
as a prolongation of the WARS into the ASE (Gohl et al. 2007, 2013a, b; Kalberg and Gohl 2014). The embayment seems to have evolved by wide-mode rather than narrowmode rifting (Kalberg and Gohl 2014). The modelled magmatic underplating can be related to a continental insulation flow, which transported magmatic material from beneath the crust of Marie Byrd Land to the Marie Byrd Seamount province offshore (Kipf et al. 2014; Kalberg and Gohl 2014).

Eagles et al. (2009) suggested extensional branches of the WARS were active around Alexander Island and in George VI Sound (GVIS), to the NE of the ASE, in the period 34-26 Ma. Additionally, recent studies of Bingham et al. (2012) showed that the Ferrigno Rift, inland of the embayment and GVIS (Fig. 1) was affected by crustal thinning that they attributed to the same causes as the WARS. Contrary to the Ross Sea and the Amundsen Sea sectors of the WARS, there seems to be no evidence for widespread Cenozoic magmatism around the Ferrigno rift region (Bingham et al. 2012). In great contrast, Granot et al. (2013) calculated Euler rotation parameters that infer these eastern reaches of the WARS would have worked in plate convergence.

Plate kinematic reconstructions of the southern Pacific realm and the West Antarctic margin (e.g. Larter et al. 2002; Eagles et al. 2004; Wobbe et al. 2012) explain reasonably well the general break-up and ocean drifting process between New Zealand and West Antarctica but suffer from sparse information on the regional tectonic architecture of the ASE lithosphere which was a key region for the initiation of rifting and break-up (Fig. 2).

This study presents a spatial insight into the lithospheric architecture of the Pacific margin of West Antarctica in the embayment between $120^{\circ} \mathrm{W}$ and $104^{\circ} \mathrm{W}$ and between $70^{\circ} \mathrm{S}$ and $74^{\circ} \mathrm{S}$ using a detailed 3-D gravity and magnetic model supported by seismic constraints. The models image the basement morphology, regional crustal thickness, and the distribution of magmatic bodies and magmatic zones in the embayment. A joint interpretation reveals several tectonic lineaments and shows rift basins within the middle and inner shelf of the embayment. Estimates of the elastic lithospheric thickness provide further constraints on the geodynamic evolution of the ASE modified after Wobbe et al. (2012).

\section{Geological background}

The tectonic blocks of West Antarctica (Dalziel and Elliot 1982) are separated from the tectonically contrasting East Antarctic cratons and mobile belts by the Transantarctic Mountains and the WARS, which is one of the world largest continental rift systems. The structural composition of the WARS is comparable to other major continental rift zones such as the East African Rift or the Basin and Range
Province (Behrendt et al. 1991; Tessensohn and Wörner 1991; LeMasurier and Landis 1996; LeMasurier 2008).

The embayment was formed as consequence of the Late Cretaceous breakup of the former Gondwana supercontinent blocks of West Antarctica and greater New Zealand (e.g. Eagles et al. 2004a; Wobbe et al. 2012). The evolution of the Pacific margin of West Antarctica since that time included several distinct tectonic phases. South-westward propagation of rifting and breakup started with the separation of Chatham Rise from the eastern Marie Byrd Land margin as early as $90 \mathrm{Ma}$ and continued to around $83 \mathrm{Ma}$ with the breakup of Campbell Plateau from central Marie Byrd Land (e.g. Mayes et al. 1990; Bradshaw et al. 1991; Larter et al. 2002; Eagles et al. 2004a; Wobbe et al. 2012).

From about 80-79 Ma, the Bellingshausen Plate began acting as an independent tectonic plate, and continued to do so until about $61 \mathrm{Ma}$ (e.g. Larter et al. 2002; Eagles et al. 2004a, b). Its incorporation into the Antarctic Plate at this time occurred as part of a major plate reorganisation in the South Pacific (Cande et al. 2000). Based on Ar-Ar dating of dredged rocks, Kipf et al. (2014) postulated that at about 65-56 Ma the Marie Byrd Seamounts were formed from magmatic material that was transported from beneath the West Antarctic continental crust by a continental insulation flow.

The eastern shelf of the embayment has been suggested as the site of a Paleozoic-Mesozoic crustal boundary between the Thurston Island crustal block in the east and the Marie Bard Land block in the west, whose apparent paleomagnetic polar wander paths differ significantly (Dalziel and Elliot 1982; Storey 1991; Grunow et al. 1991). Müller et al. (2007) considered that the WARS east of the Ross Sea started acting in dextral strike-slip or extensional motion east of the embayment between chrons 21 and 8 (48-26 Ma.). They postulated that this motion was connected to a PacificPhoenix-East Antarctica triple junction at the southwestern Bellingshausen Sea margin via the Bentley Subglacial Trench (Fretwell et al. 2013) and the Byrd Subglacial Basin.

Moho depth estimates under the Byrd Subglacial Basin and the Pine Island Rift reveal crust of only $19 \mathrm{~km}$ thickness (Jordan et al. 2010). An estimate of the region's flexural rigidity suggests an effective elastic thickness of just $5 \mathrm{~km}$ in the same area (Jordan et al. 2010). These results infer continental thinning in this part of West Antarctica, which Jordan et al. (2010) interpreted to be generated by distributed Cretaceous rifting followed by Cenozoic narrow-mode rifting. Crustal thickness estimates based on receiver functions reveal a crustal thickness of about $17 \mathrm{~km}$ in parts of the western WARS (Chaput et al. 2014). Recent analyses of geophysical data from the Amundsen Sea shelf show that sedimentary sub-basins and tectonic lineaments cross the shelf, some of which can be related to an eastern branch of the WARS (Gohl et al. 2013a, b, Kalberg and Gohl 2014). A continuous 2-D 

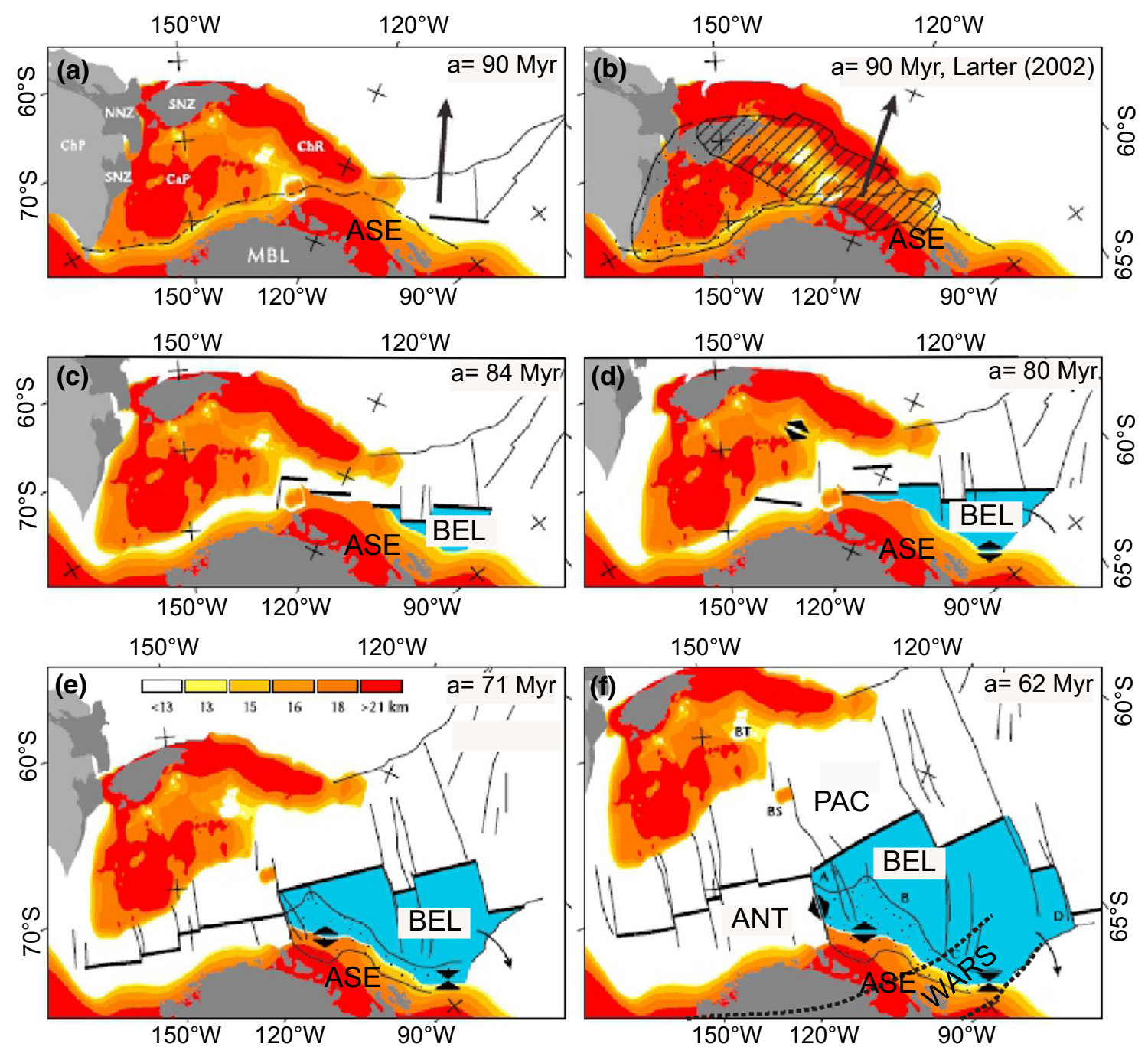

Fig. 2 Schematic plate-tectonic reconstruction model of distinct tectonic phases in the SW Pacific from Late Cretaceous to early Paleocene (modified after Wobbe et al. 2012) using rotation parameters of Grobys et al. (2008) and Wobbe et al. (2012) in (a) and (c-f), and rotation parameters of Larter et al. (2002) in (b). The black arrows in (a) and (b) show the movement direction of the Bellingshausen Plate. Thin black lines show fracture zones, thick black lines show mid ocean ridge segments. The thin black dashed line indicates the presumed eastern rift branch of the West Antarctic

continental rise to shelf gravity model shows $12-29 \mathrm{~km}$ thick continental crust that seems to have been thinned during wide-mode rifting (Kalberg and Gohl 2014). Recent Apatite-He age trends derived from rock samples of the eastern Pine Island Bay infer rift-related block faulting (Lindow et al. 2011). In this context, it seems likely that the topographic depression of the present glacially-formed Pine Island Trough on the eastern shelf may have originated by extensional tectonic activity related to development of the WARS. West of Pine Island Bay, thermochronological analysis of the Mt. Murphy block and its neighbouring areas reveals a history of differential
Rift System (Gohl et al. 2013a, b). Dotted area in (e) and (f) shows oceanic crust which was formed along the Bellingshausen Plate margin. e includes the crustal thickness scale of Wobbe et al. (2012). ANT West Antarctic plate, BEL Bellingshausen plate, $B S$ Bollons Seamount, BT Bounty Trough, $C a P$ Campbell Plateau, ChP Challenger Plateau, ChR Chatham Rise, $M B L$ Marie Byrd Land, NNZ North Island of New Zealand, PAC Pacific plate, SNZ South Island, ASE Amundsen Sea Embayment, WARS West Antarctic Rift System, ASE Amundsen Sea Embayment

burial and uplift that is interpreted in terms of Oligocene motions on a major fault system (Lindow et al. 2011).

\section{Data acquisition and processing}

\section{Database}

The gravity data comprise the satellite-derived free-air gravity anomaly (FAA) from McAdoo and Laxon (1999) (Fig. 3a). We calculated the Bouguer anomaly (Fig. 3b) based on the FAA and the bathymetric grid of Nitsche et al. 
(2007), using a Bouguer reduction density of $2.67 \mathrm{~g} / \mathrm{cm}^{3}$. Figure $3 c$ shows a magnetic anomaly grid of the ASE. Gohl et al. (2013a) describe the experimental setup, data processing and gridding procedure from helicopter and shipborne magnetic data collected during two RV Polarstern expeditions in 2006 and 2010, and go on to interpret the grid with the help of a set of 2-D forward models.

We constrained the crustal thickness and density distributions in our gravity model by using the results of published seismic reflection data and forward modelling of three seismic refraction profiles (Gohl et al. 2007; Uenzelmann-Neben et al. 2007; Weigelt et al. 2009; Uenzelmann-Neben and Gohl 2012, 2014; Gohl et al. 2013b; Hochmuth and Gohl 2013; Kalberg and Gohl 2014; Gohl et al. 2013b; Kalberg and Gohl 2014). Where no deep crustal seismic data are available, we used the results of a power spectrum analysis of the gravity and magnetic data.

\section{Data description}

\section{Free-air anomaly}

The FAA of the outer shelf is dominated by two gravity highs of up to $+80 \mathrm{mGal}$ corresponding to the bathymetrically elevated Eastern and Western Outer banks (Gohl et al. 2013b) (Fig. 3a) A characteristic feature of the middle shelf area is a major WSW-ENE trending negative anomaly with a minimum of $-70 \mathrm{mGal}$, named the Amundsen Sea Embayment Low (Kalberg and Gohl 2014). This anomaly is interrupted by the prominent northwest-southeast trending Peacock Gravity Anomaly (Cunningham et al. 2002) and continues north of Thurston Island as the Thurston Island Low (Kalberg and Gohl 2014). Pine Island Bay at the inner shelf is divided by the north-striking glacial Pine Island Trough with a gravity low of $-50 \mathrm{mGal}$.

\section{(a)}

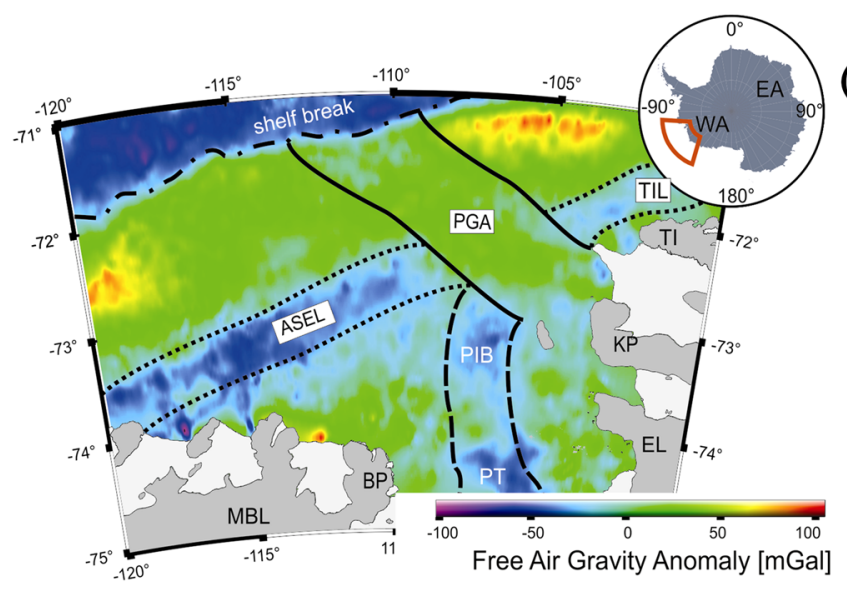

(b)

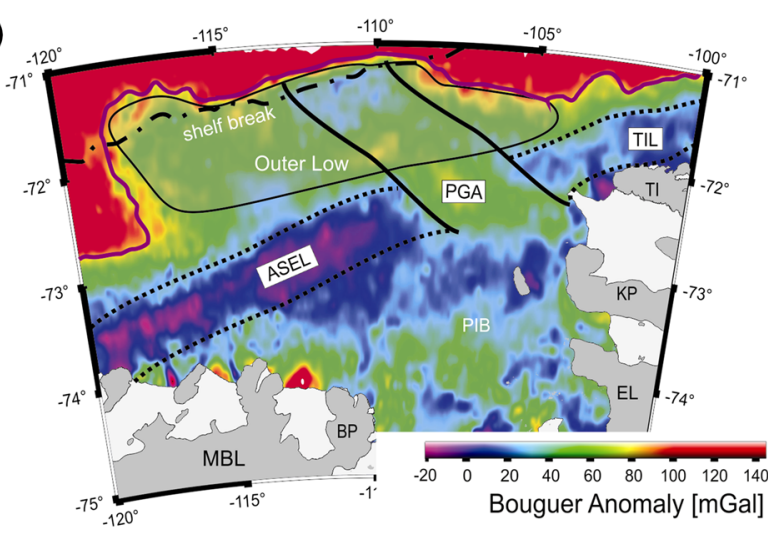

(c)

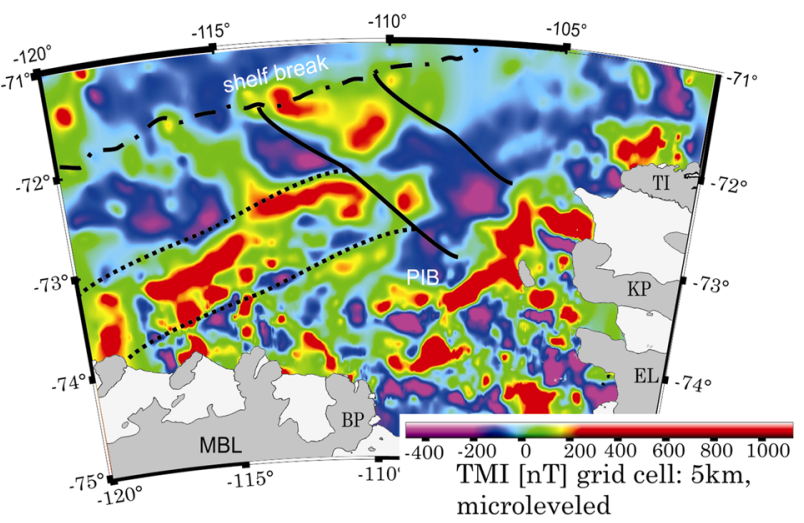

Fig. 3 Compilation of gravity and magnetic data. Figure 3 a maps the satellite-derived free-air gravity anomaly of the Amundsen Sea Embayment (McAdoo and Laxon 1999). The thin black dotted and continuous lines mark prominent gravity anomalies along the middle and outer shelf of the Amundsen Sea Embayment. Figure $3 \mathrm{~b}$ maps the calculated Bouguer Anomaly. The framed semi-transparent area beneath shelf break shows a prominent low (Outer Low). The thick black dotted line marks a 2-D gravity rise-to-shelf model transect (Kalberg and Gohl 2014). Figure 3c shows the magnetic anomaly map of the ASE (Gohl et al. 2013a). ASEL Amundsen Sea Embayment Low, TIL Thurston Island Low, PGA Peacock Gravity Anomaly, $P T$ Pine Island Trough, $B P$ Bear Peninsula, PIB Pine Island Bay, $M B L$ Marie Byrd Land, EL Ellsworth Land, TI Thurston Island, $K P$ King Peninsula, PIB Pine Island Bay 


\section{Bouguer anomaly}

The gravitational influence of the bathymetry can be removed from the FAA by calculating the Bouguer Anomaly (BA) such that only the effects of rock density variations in the subsurface are retained. The inner shelf of the ASE is dominated by short wavelength anomalies of between 0 and $+70 \mathrm{mGal}$ whereas the outer shelf shows predominantly long wavelength anomalies between -20 and $+70 \mathrm{mGal}$ that correlate with bodies modelled in recent magnetic data collected in the embayment (Gohl et al. 2013a).

As in the FAA, the ASE and Thurston Island lows (Kalberg and Gohl 2014) appear as a WSW-ENE trending anomaly that dominates the middle shelf (Fig. 3b) and is interrupted by the positive Peacock Gravity Anomaly. The outer shelf area is dominated by a major gravity low, named Outer Low (Kalberg and Gohl 2014) of up to $+80 \mathrm{mGal}$. The boundary between the outcropping basement of the inner shelf and the sedimentary basin of the middle and outer shelf (Gohl et al. 2013a, b) corresponds to a step in the BA from 0 to $+50 \mathrm{mGal}$.

\section{Magnetic data}

The outer and the middle shelf areas of the Amundsen Sea shelf are dominated by long wavelength NW-SE trending magnetic anomalies (Fig. 3c) crossing the Peacock Gravity Anomaly (Fig. 3a, b). Recent studies have related these anomalies to fault-bounded basins formed by rift processes that occurred before breakup as early as $100 \mathrm{Ma}$ and during breakup between 90 and 83 Ma (Gohl 2012; Wobbe et al. 2012; Gohl et al. 2013a). The inner shelf shows predominately short wavelength anomalies (Fig. 3c). The transition from long to short wavelength magnetic anomalies is interpreted to be the signature of a boundary between sediment-covered basement and outcropping basement (Gohl et al. 2013a) (Fig. 3c).

\section{Spectral analysis}

As directly measured crustal thickness is only available from two seismic refraction profiles in the western ASE (Kalberg and Gohl 2014) (Fig. 1b), we use spectral analysis of the potential field data to derive crustal thicknesses for the entire embayment. We calculated the depth of interfaces with significant density and susceptibility contrast by using a power spectral analysis of the FAA and the magnetic data. This method was initially developed for magnetic data (Spector and Grant 1970) and upgraded for gravity data (Dorman and Lewis 1970; Syberg 1972; Karner and Watts 1983).
The power spectral analysis is based on the assumption that the source of an anomaly field can be regarded as a collection of flat-topped prisms of different heights below the measurement surface. With this assumption, the natural logarithm of the power spectrum of the field should portray a set of linear facets when plotted against wave number $\left(\mathrm{k}_{\mathrm{r}}\right)$. The gradients of the facets can be used to interpret the mean depths to the sources.

We chose three sub-areas for the power spectral analysis. Ideally, the chosen areas should contain provinces of relatively uniform geology, but should also be large enough to resolve longer wavelengths and, therefore, greater target depths. Hence, the chosen window size of $200 \mathrm{~km}^{2}$ is a result of a compromise for these considerations. The analysed areas cover the continental slope and rise (I) as well as the middle (II) and inner shelf area (III) (Fig. 1b). The uncertainty of the depth calculation is controlled by the sampling resolution and can be estimated to be around $2 \mathrm{~km}$ (Cianciara and Marcak 1976). Studinger (2001) showed that the information contents in the low-frequency parts of the spectra of satellite-derived and aero-gravity data are comparable, and thus that the differences between crustal thickness estimates based on the two sources are negligible.

The results of the power spectral analysis are presented in Figs. 4, 5 and summarized in Table 1. At first glance, it is evident that the crustal thickness estimates based on the power spectral analysis and the crustal thickness derived from seismic refraction data (Kalberg and Gohl 2014) are comparable.

The power spectral analyses of the FAA in all three subareas show two linear segments corresponding to distinct density interfaces (Fig. 4). At the Nyquist wave number $\left(0.50 \mathrm{~km}^{-1}\right)$, the power spectrum flattens out in the highfrequency domain and gives way to white noise. Spectral analysis of Gohl et al.'s (2013a) magnetic anomaly grid of the ASE reveal three linear segments in all three areas (Fig. 5). Similar to the gravity data, the power spectral analysis of the magnetic data flattens out at high frequencies and gives way to white noise at a Nyquist wave number of $0.80 \mathrm{~km}^{-1}$.

\section{Potential field modelling}

We used the potential field forward modelling software IGMAS (Götze and Lahmeyer 1988) to calculate the 3-D effects of anomalous bodies in the subsurface. The gravity or magnetic effect is calculated for a set of triangulated polyhedrons generated from polygons drawn along parallel vertical cross-sections. Density or magnetic susceptibility values are then assigned to each of these polygons.

Our starting model comprises 22 parallel vertical planes, which are orientated from north to south and cross the shelf 
Fig. 4 The power spectrum analysis of free-air gravity data of McAdoo and Laxxon (1999) (Fig. 3a). I, II and II are plots of the natural logarithm of the radially averaged power spectra (PSD) as a function of radial wave number kr. Plots I-III correspond to divisions shown in Fig. 1b. The black dots show the values of the energy spectra and the grey lines are the result of a linear regression for the depth estimation. Anomaly mass depth is presented in $\mathrm{km}$. Mean depth to anomaly mass depth are estimated from the slope of the corresponding PSD's
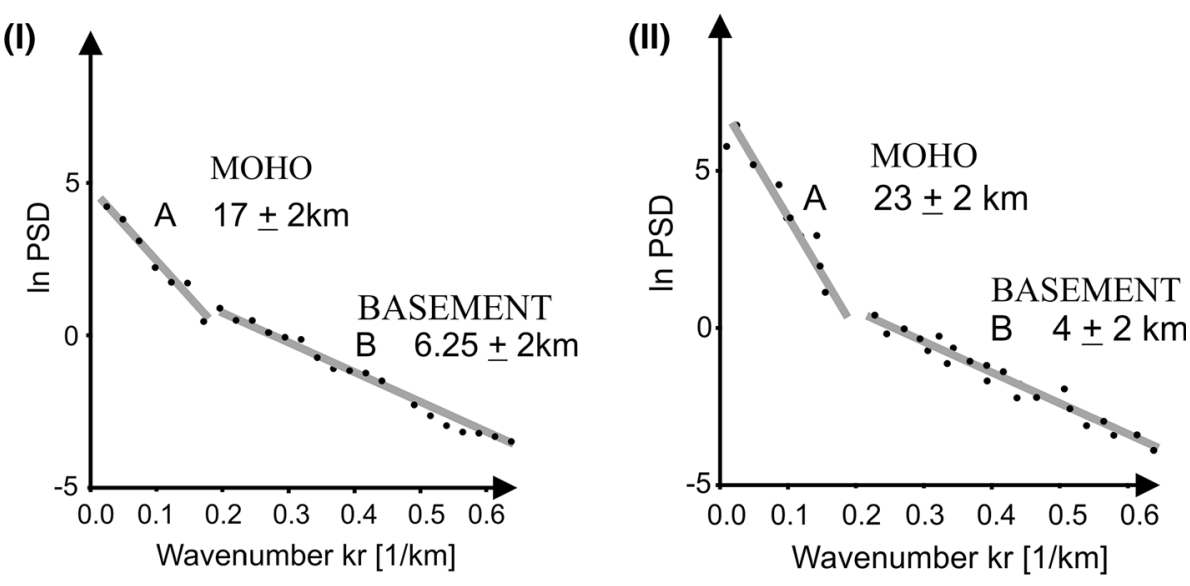

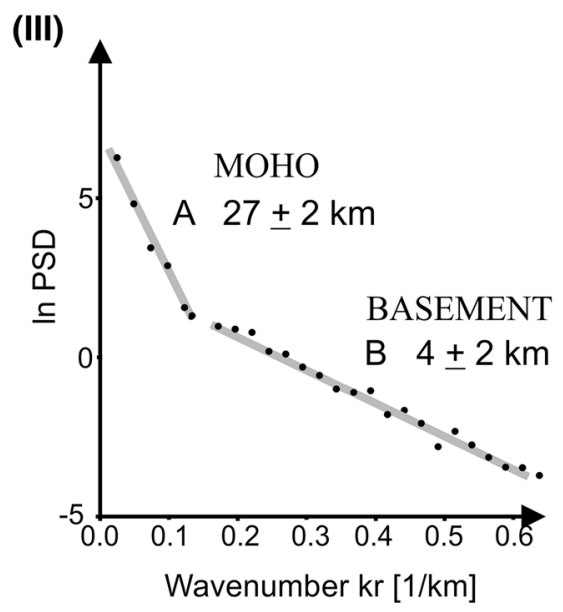

break of the ASE. The spacing between each pair of $500 \mathrm{~km}$ long planes is $25 \mathrm{~km}$. The modelled area presented in this study covers an area of $275,000 \mathrm{~km}^{2}$ between $70^{\circ} \mathrm{S}$ and $74^{\circ} \mathrm{S}$ and between $104^{\circ} \mathrm{W}$ and $120^{\circ} \mathrm{W}$ (Fig. 1b). To avoid edge effects, the flanking planes (planes 1 and 22) are modelled at distances of $1000 \mathrm{~km}$ eastward and westward of the region.

\section{Density-depth modelling}

To simplify our starting model, we treated all the sedimentary units as a single layer with an average density of $2050 \mathrm{~kg} / \mathrm{m}^{3}$ (Kalberg and Gohl. 2014). We used a maximum model depth below sea-level of $30 \mathrm{~km}$. P-wave velocities of the crystalline crust in the embayment infer continental affinity (Kalberg and Gohl 2014). We used the velocity-density relationship for continental crust of Barton (1986) for calculating crustal densities based on the seismic refraction data. The upper-crustal density was $2650 \mathrm{~kg} / \mathrm{m}^{3}$ and the lower-crustal density was $2800 \mathrm{~kg} / \mathrm{m}^{3}$ (Kalberg and Gohl. 2014). Further, we modelled an intracrustal layer based on latest seismic refraction observations in the embayment with a density of $3150 \mathrm{~kg} / \mathrm{m}^{3}$ (Kalberg and
Gohl. 2014) as well as mafic intrusive bodies with a moderately high density of $3000 \mathrm{~kg} / \mathrm{m}^{3}$. The uppermost mantle was modelled with a density of $3300 \mathrm{~kg} / \mathrm{m}^{3}$.

The standard deviation between the observed (Fig. 6a) and modelled FAA's (Fig. 6b) is $6.78 \mathrm{mGal}$ for the entire ASE. Differences between the modelled and the measured FAA can be explained by out-of-plane effects and edge effects at the shelf edge. Uncertainty of $100 \mathrm{~kg} / \mathrm{m}^{3}$ for the density of the high-density body infers an uncertainty of $1 \mathrm{~km}$ in crustal thickness.

The depth of the Moho below sea-level increases from $14 \mathrm{~km}$ at the continental rise to $29 \mathrm{~km}$ at the inner shelf of the ASE (Figs. 7, 8, 9a). Above this, the entire embayment is underlain by a high-density lower crust of thickness varying between 1 and $10 \mathrm{~km}$, from north to south (Fig. 7). At the continental rise in the eastern embayment, we modelled the top of basement at 7.5-9.0 km to be covered by $1.0-4.5 \mathrm{~km}$ of sedimentary rocks. This geometry is confirmed in seismic and bathymetric data (Figs. 8, 9b) (Gohl et al. 2013a, b; Kalberg and Gohl 2014; Nitsche et al. 2007, 2013). The outer shelf of the western embayment is characterized by shallower basement at $4-5 \mathrm{~km}$ depth beneath the Western Outer Bank (Gohl et al. 2013b). 
Fig. 5 Power spectra of magnetic data (Fig. 3c) in the same area as shown in Fig. 4. Anomaly mass depth is also presented in $\mathrm{km}$
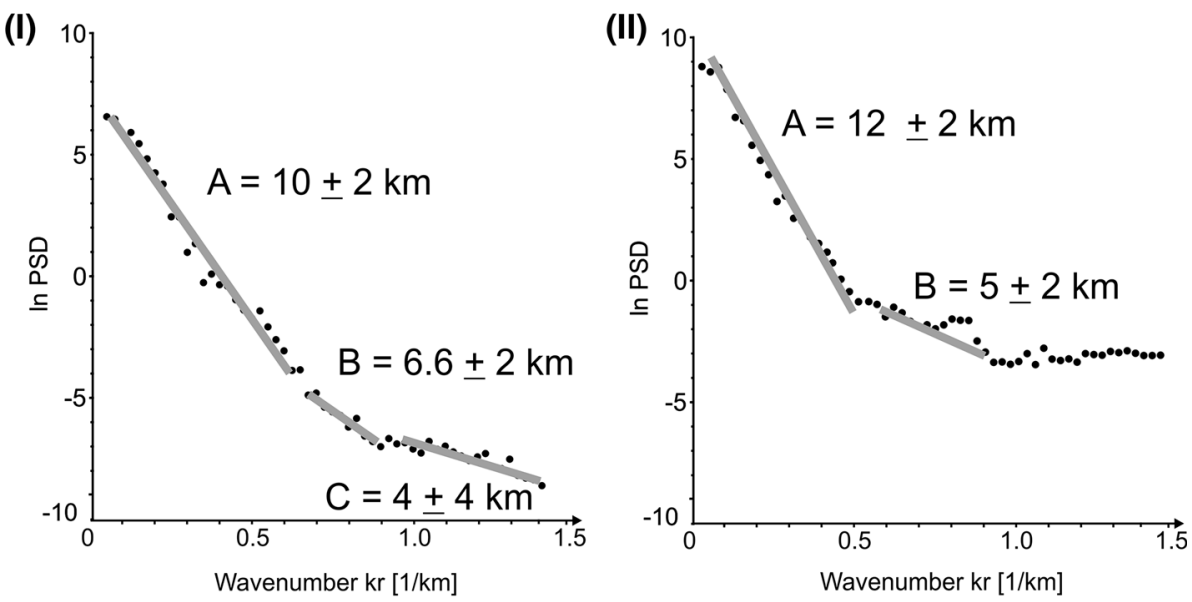

(III)

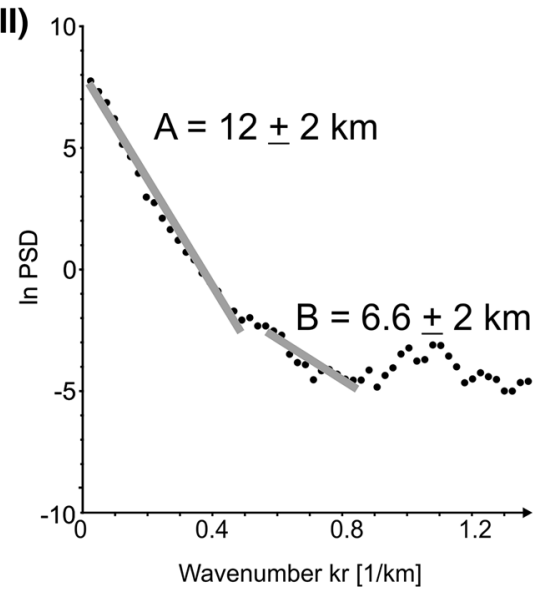

Table 1 Results of the spectral analysis of the gravity and magnetic data presented in Figs. 4 and 5

\begin{tabular}{llll}
\hline Area & $\mathrm{A}(\mathrm{km})$ & $\mathrm{B}(\mathrm{km})$ & $\mathrm{C}(\mathrm{km})$ \\
\hline Gravity & & & - \\
I & $17.0(2)$ & $6.0(2)$ & - \\
II & $23.0(2)$ & $4.0(2)$ & - \\
III & $27.0(2)$ & $4.0(2)$ & $4(2)$ \\
Magnetic & & & $0(2)$ \\
I & $10.0(2)$ & $6.6(2)$ & $0(4)$ \\
II & $12.0(2)$ & $5.0(3)$ & $6.6(2)$ \\
III & $12.0(2)$ & & \\
\hline
\end{tabular}

The distinct linear regressions A, B and C are labelled in Figs. 4 and 5

Seismic data confirm the model depiction of a shallower level basement over parts of the shelf edge of the eastern embayment (Fig. 9b; Hochmuth and Gohl 2013). The model shows NE-SW trending basins crossing the central and eastern parts of the middle shelf, filled with $6 \mathrm{~km}$ or more of sediments (Fig. 9b). South of these basins, the topof-model-basement is only very shallowly buried or exposed (Fig. 9a, b), as can be observed or inferred in seismic and magnetic data (Gohl et al. 2013a, b).

\section{Magnetic modelling}

Magnetic modelling used a magnetic declination of $50^{\circ}$, an inclination of $-67^{\circ}$ and a 50,000 nT background reference field (Maus et al. 2010). Depth estimates based on spectral analysis of our magnetic anomaly data provided constraints for an initial 3-D magnetic anomaly model. Further, results of an Euler deconvolution (Gohl et al. 2013a) were used to locate the tops and edges of magnetic sources. The Euler deconvolution suggests the tops of distinct source bodies may be found at depths of $7 \mathrm{~km}$ below sea-level on the outer and the middle shelf, but that the tops of inner shelf source bodies may be much shallower (Gohl et al. 2013a). The maximum model depth was fixed at $16 \mathrm{~km}$ in view of an estimated Curie depth of $16 \mathrm{~km}$ beneath the central Amundsen Sea shelf (Denk 2011). Above this, the top of basement was estimated from seismic data (Weigelt et al. 2009; Gohl et al. 2013b; Kalberg and Gohl. 2014).

Although the magnetic susceptibilities of different rock types can vary by several orders of magnitude, it is possible to use them to distinguish generally between sedimentary (0.000005 SI), mafic (0.0001-0.13 SI) or felsic (0.0001$0.02 \mathrm{SI}$ ) rock compositions (Domack and Ishman 1992; 
(a)

(b)

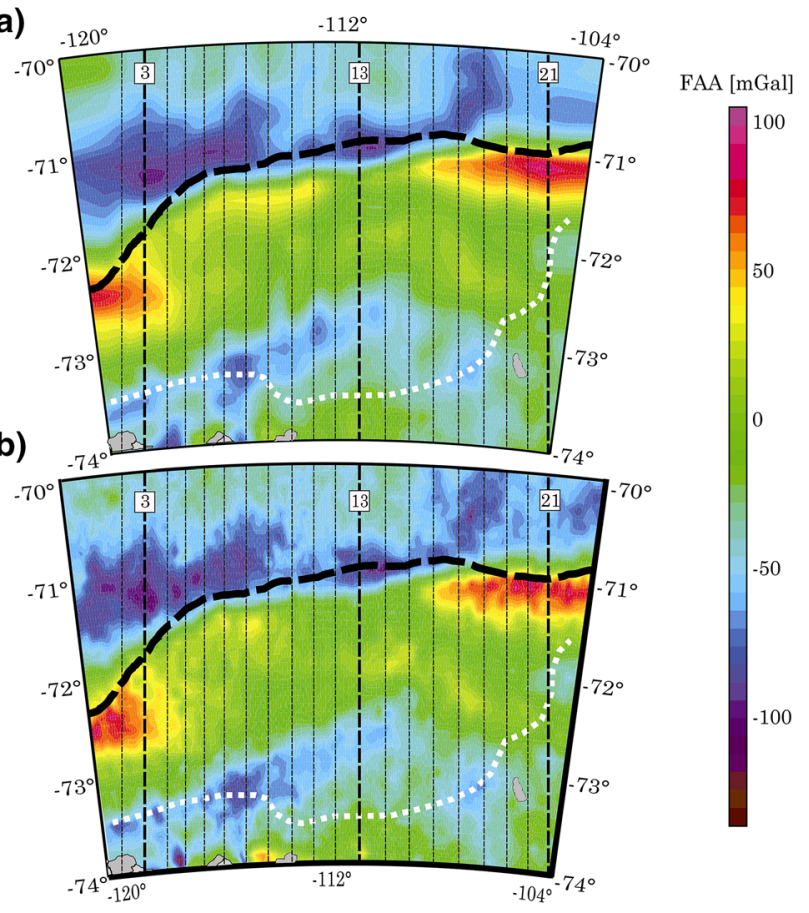

Fig. 6 a Maps the modelled free air gravity anomaly of the Amundsen Sea Embayment. b Images the measured free-air gravity anomaly (McAdoo and Laxon 1999). The three vertical thick black dashed lines show the position of three example vertical layers 3, 13 and 21 which are shown in Fig. 8. Thin dashed vertical black lines show the position of all other model layers which are shown in Fig. 9 The thick black dashed line images the shelf break and the dashed white line shows outcropping basement (Gohl et al. 2013a, b)

Sanger and Glen 2003). In our model, we used susceptibilities of $0.000005 \mathrm{SI}$ for the sedimentary layer, $0.001 \mathrm{SI}$ for the crystalline continental crust, and 0.08 for mafic intrusive bodies.

The standard deviation between the measured (Fig. 10a) and modelled total anomaly field (Fig. 10b) is $50.8 \mathrm{nT}$ which corresponds to a model error of about $3.5 \%$. As for the gravity model, differences between the modelled and the measured magnetic anomalies can be explained by outof-plane and edge effects of intrusive bodies. For simplicity, and given the lack of independent constraints, we used a single susceptibility value for all intrusive bodies in the embayment. Below the outer and middle shelf, most of the source bodies are deep-seated, whereas intrusions below the inner shelf top close to the seafloor. In contrast to the gravity modelling, the basement morphology has no significant influence on the long wavelength magnetic anomaly field. Magnetic anomalies associated with the basins of the middle and inner shelf of the eastern embayment are modelled by susceptibilities consistent with the presence of mafic intrusions (Figs. 11, 12). The locations of the strong susceptibilities correlate with modelled high-density bodies in the 3D gravity model (Figs. 7, 8).

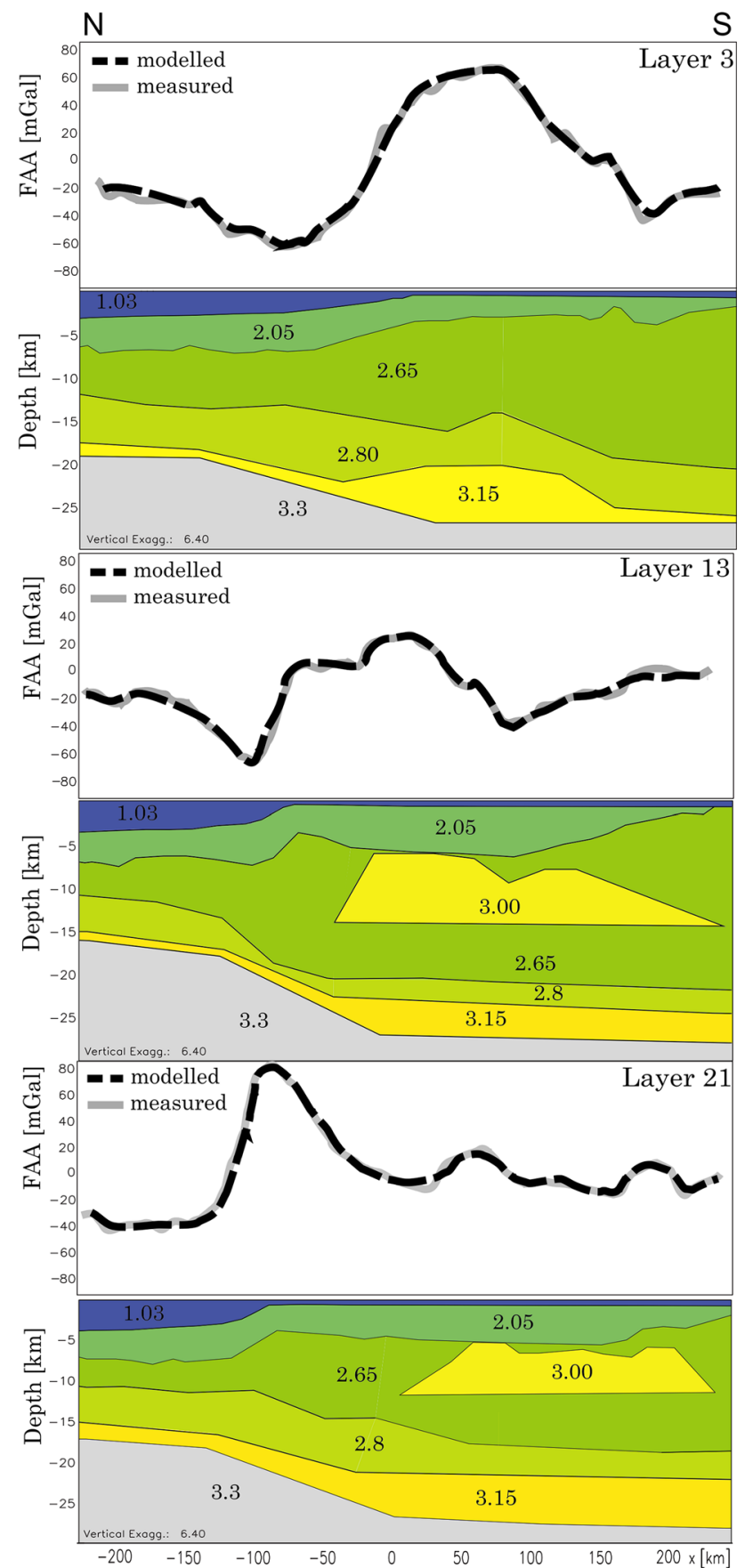

Fig. 7 2-D forward gravity models of the example layers 3, 13 and 21 (Fig. 8). Database is the satellite-derived gravity data from McAdoo and Laxon (1999), crustal informations derived from a spectral analysis of the satellite-derived gravity data of McAdoo and Laxon (1999) and a previous 2-D model in the western embayment (Kalberg and Gohl 2014). Bathymetric surface is after Nitsche et al. (2007). Density values are given in $10^{3} \mathrm{~kg} / \mathrm{m}^{3}$

\section{Elastic thickness $(T e)$ estimation}

The effective elastic thickness $(T e)$ of the lithosphere is a parameter of its rigidity, and is calculated via its flexural response to sedimentary or topographic loading under the 


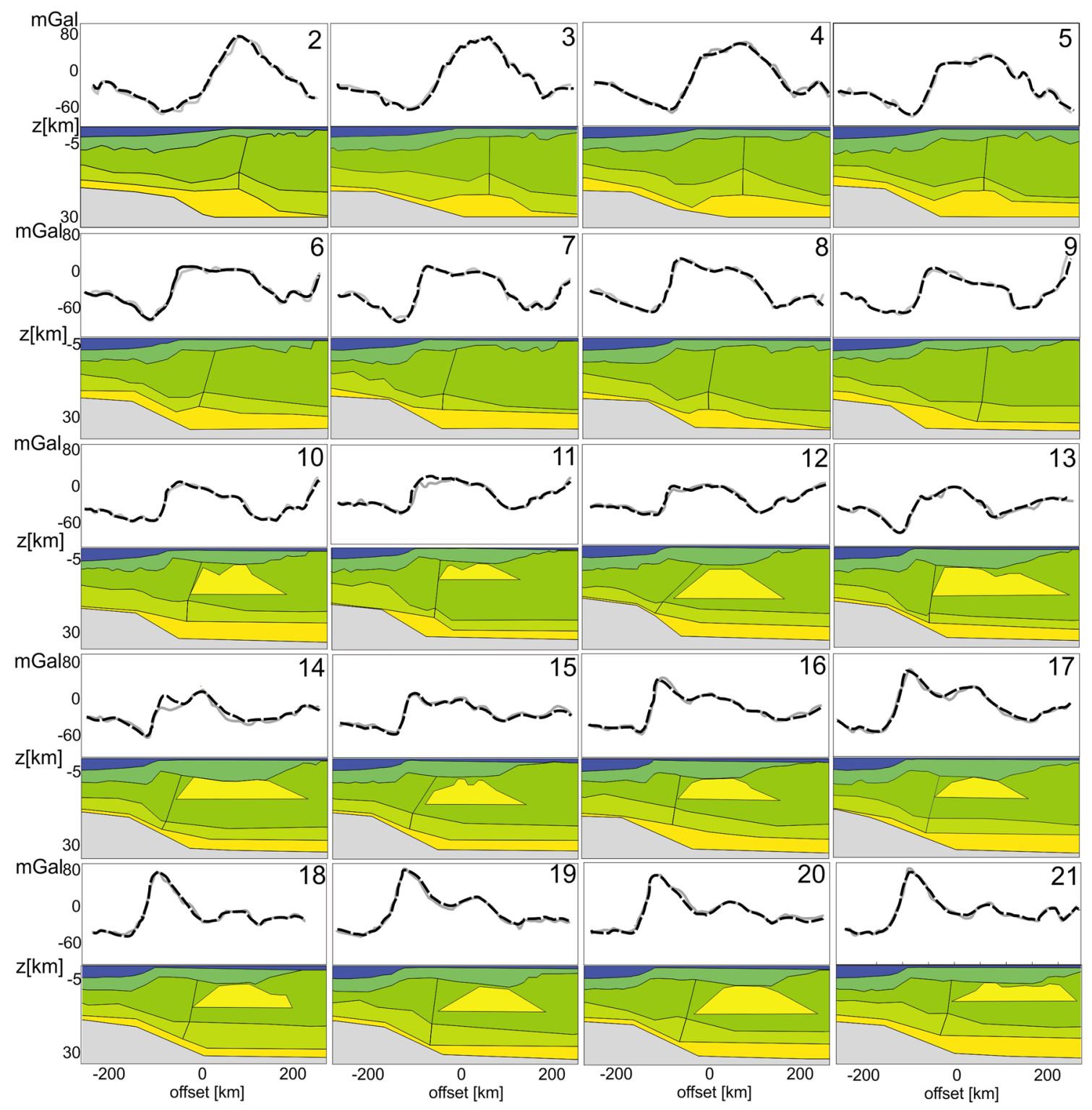

Fig. 8 2-D forward gravity modeling results of all layers. Database and density-colour codification is the same as for the three example layers in Fig. 7

assumption that this response is like that of an elastic plate with thickness $T e$ (Watts 2001). As temperature is considered to be a control on lithospheric strength, the flexural rigidity of the lithosphere might be expected to increase with time since rifting of part of the lithosphere and so might be used to determine the rifting process.

We used the software LITHOFLEX to obtain an estimate of flexural rigidity in the ASE (Braitenberg et al. 2007). LITHOFLEX provides a suite of utilities to study the isostatic state, rheologic properties and the elastic thickness of the lithosphere. In addition, the program includes a set of utilities that allow forward and inverse calculation of the gravity field. LITHOFLEX requires the crustal load and
Moho depth, which are available from our 3-D densitydepth model (Figs. 7, 8, 9) and seismic data (Gohl et al. 2013b; Kalberg and Gohl 2014). The crustal load can be defined by the so-called "equivalent topography" or "rock equivalent topography" (RET). RET is a representation of the Earths topography that combines ocean water and ice into layers equivalent to the density of topographic rock, while keeping the water and ice masses constant. Hence, RET allows the computation of the gravity effect based on a single constant mass-density layer.

We calculated RET with LITHOFLEX using the bathymetry of Nitsche et al. (2007), the water density $\left(1030 \mathrm{~kg} / \mathrm{m}^{3}\right)$ and an average crustal density $\left(2800 \mathrm{~kg} / \mathrm{m}^{3}\right)$ 
(a)

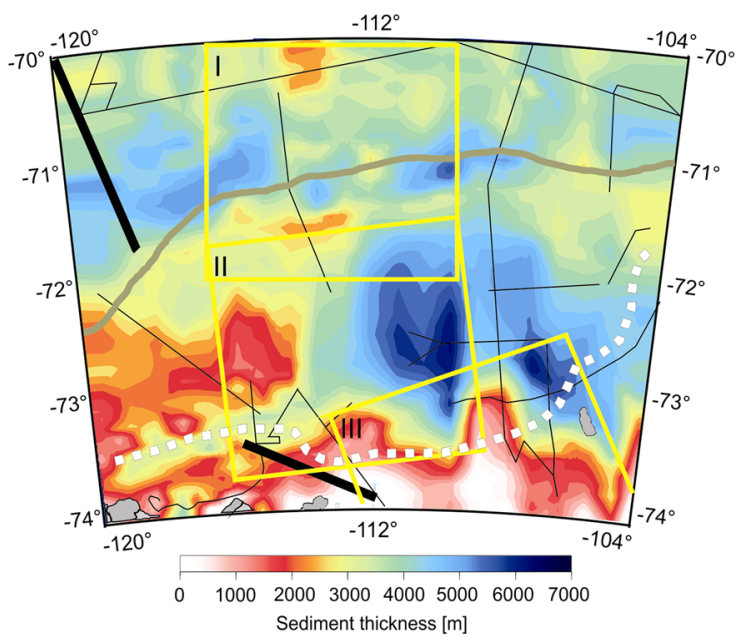

(b)

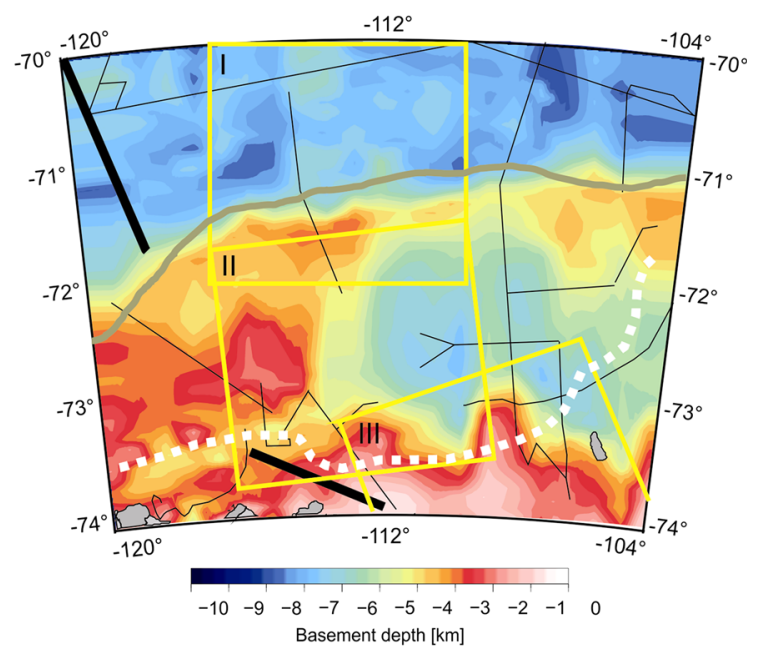

(c)

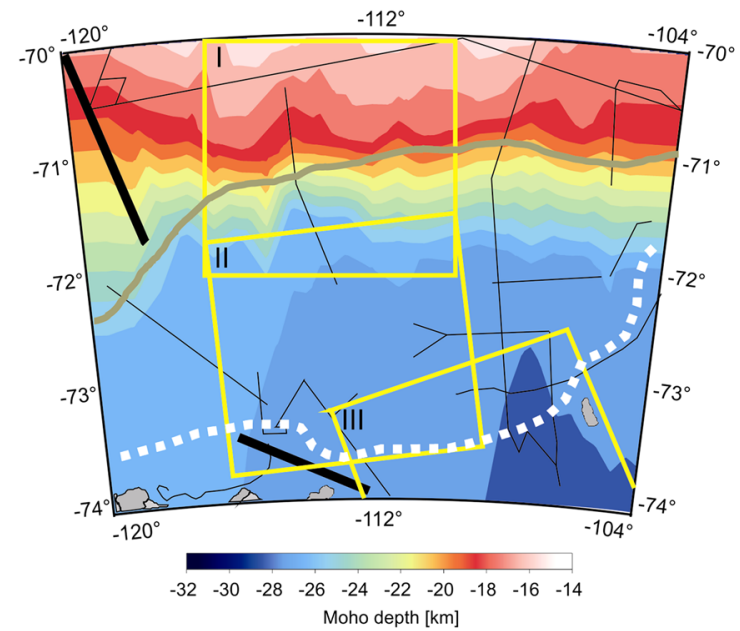

Fig. 9 Features derived from 3-D forward gravity modelling. a Sedimentary thickness map of the Amundsen Sea Embayment. b Basement depth in the ASE. c Moho depth. Thin black lines illustrate multi-channel seismic reflection profiles and the two thick black lines show deep crustal seismic refraction profiles in the western

(Kalberg and Gohl. 2014). As the ice sheet in the Amundsen Sea sector is grounded relatively far inland of the rifted parts of the embayment, we ignore the effect of the ice sheet and argue that this has no significant influence on the isostatic state of the shelf. We calculate the flexural rigidity with respect to the known sedimentary cover and the known crustal thickness.

Based on this method, it is possible to divide the ASE into different lithospheric areas, which can be interpreted according to their geological significance. The best fitting lithospheric $\mathrm{T}_{\mathrm{e}}$ model (Fig. 13) exhibits an elastic thickness increasing from 10 to $15 \mathrm{~km}$ in the eastern embayment, from 10 to $20 \mathrm{~km}$ in the western embayment and from 0 to $5 \mathrm{~km}$ in Pine Island Bay, which is therefore the weakest part of the Embayment. embayment (Kalberg and Gohl 2014). The three yellow frames show the windows I-III which were used for spectral analysis of the magnetic and gravity data (Fig. 1b). The thick white dotted line shows the northerly limit of outcropping or shallow basement as interpreted from magnetic anomalies (Gohl et al. 2013a, b)

\section{Interpretation and discussion}

\section{Lithospheric and crustal structure}

The transition from oceanic to continental crust can be clearly identified at a gradient towards more positive values beyond the shelf break in the Bouguer anomaly (Fig. 3b). The Outer Low over the Western Outer Bank of the ASE shelf (Fig. 3a) comprises a terrace in this signal and a basement terrace in our gravity model. Unlike in the FAA, the Bouguer Anomaly is not ubiquitous beneath the outer shelf, indicating that its source is not of topographic nature. We interpret it to indicate a buried horst block, possibly a remnant from Cretaceous extension that led to the separation of West Antarctica and Zealandia. 


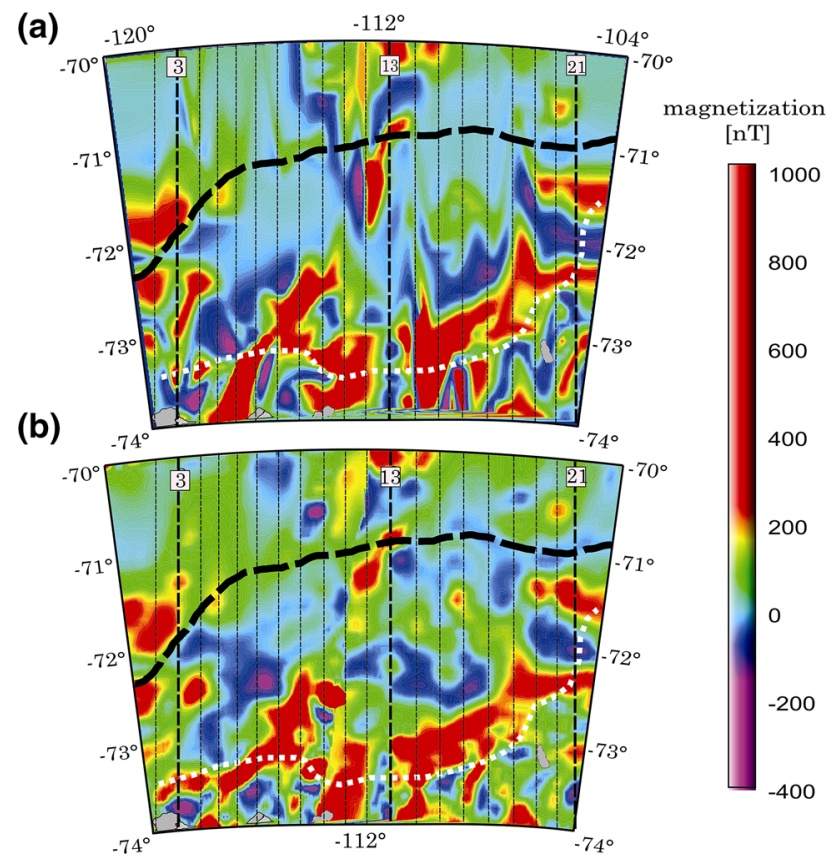

Fig. 10 The modelled magnetic anomaly map of the Amundsen Sea Embayment. b images the measured magnetic anomaly map (Gohl et al. 2013a). The three vertical black dashed lines show the position of the three example slices 3, 13 and 21 which are shown in Fig. 11 and the thin dashed lines show the locations of all other slices. The thick black dashed line images the shelf break and the thick white dashed line marks the outcropping basement (Gohl et al. 2013a, b)

The basement morphology in the ASE is interpreted to be the result of distributed crustal rifting and deformation, leaving a buried network of failed rifts and rift-related accommodation zones (Gohl et al. 2013b; Kalberg and Gohl 2014). These sedimentary sub-basins of the middle and outer shelf can be related to the long tectonic history of the embayment. The basement ridge in the western embayment (Fig. 9b) follows an ENE-WSW trending positive gravity anomaly (Fig. 3a, b) and might be related to uplift over a high-density magmatic layer, possibly a part of a lithospheric mantle, transported from Marie Byrd Land by a postulated continental insulation flow (Kalberg and Gohl 2014; Kipf et al. 2014) (Fig. 8).

The basement topography of the western embayment (Figs. 9, 10) may have determined its preglacial geomorphology. We infer that the basement ridges (Fig. 9a) may have set the template for past ice flow trends as has been interpreted for the eastern embayment (Gohl et al. 2013b; Hochmuth and Gohl 2013). The two deep sub-basins in the eastern embayment also parallel the major glacial troughs such as the Pine Island Trough and Abbot Trough.

The intrusive bodies of moderately high-density $\left(3000 \mathrm{~kg} / \mathrm{m}^{3}\right)$ are interpreted to consist of cumulated gabbro resulting from partial melting of the lithospheric mantle. The correlation between these high-susceptibility

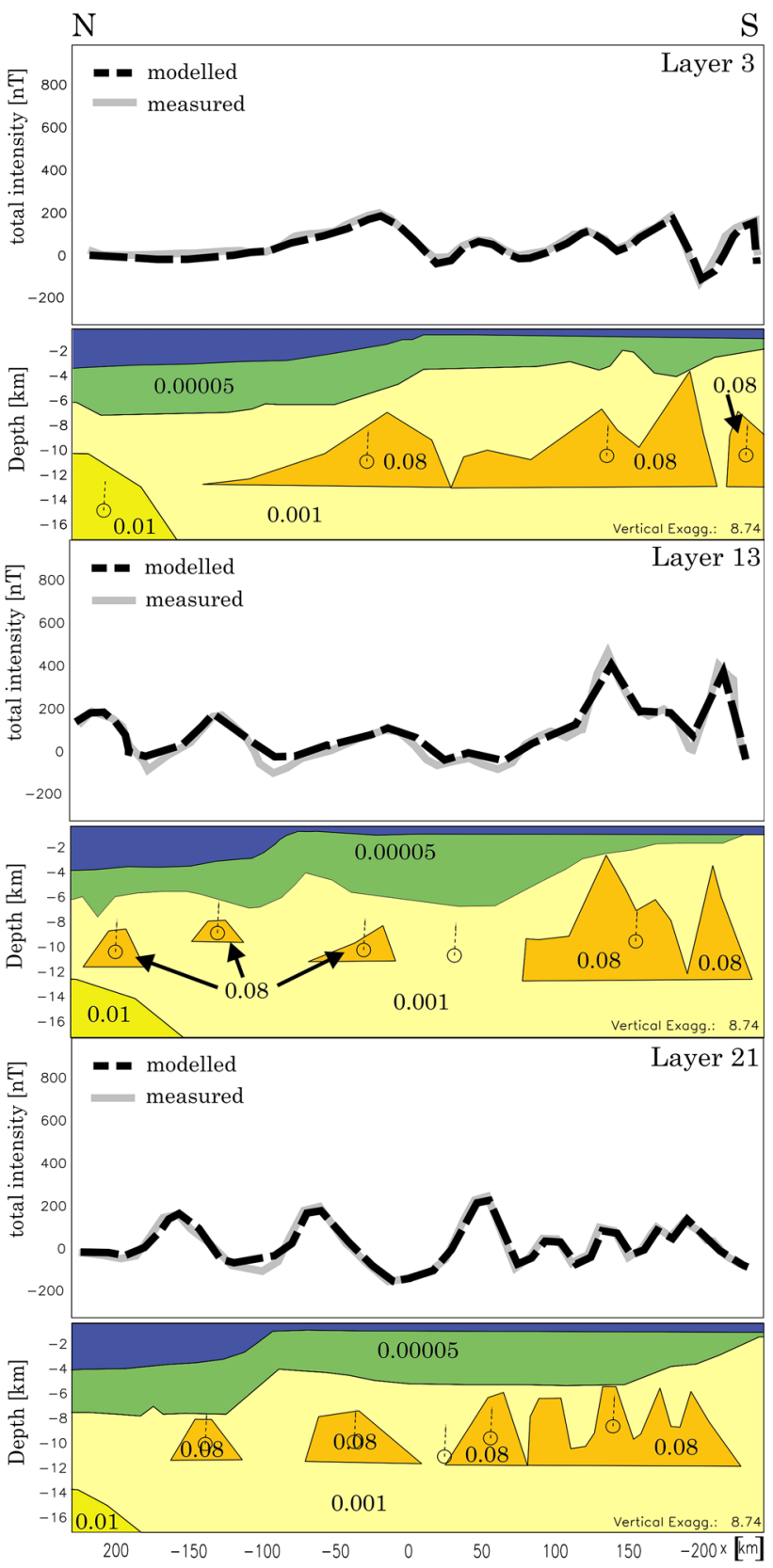

Fig. 11 2-D forward magnetic models of the example layers 3, 13 and 21 (Fig. 12). Database is the measured magnetic anomaly map of the ASE from Gohl (2012), mass anomaly depth estimations derived from a power spectral analysis of the magnetic data (Fig. 6) and a previous 2-D magnetic model in the western embayment (Gohl 2012). Bathymetric surface is after Nitsche et al. (2007) and the basement structure was derived from seismic observations. Susceptibility values are given in SI

and high-density bodies is better in the eastern than in the western embayment. Only mafic intrusions produce both significant magnetic and positive gravity anomalies (Sterritt 2006). Hence, we suggest the eastern embayment hosts a greater concentration of mafic intrusions than the western embayment, where intrusions may be of more felsic 

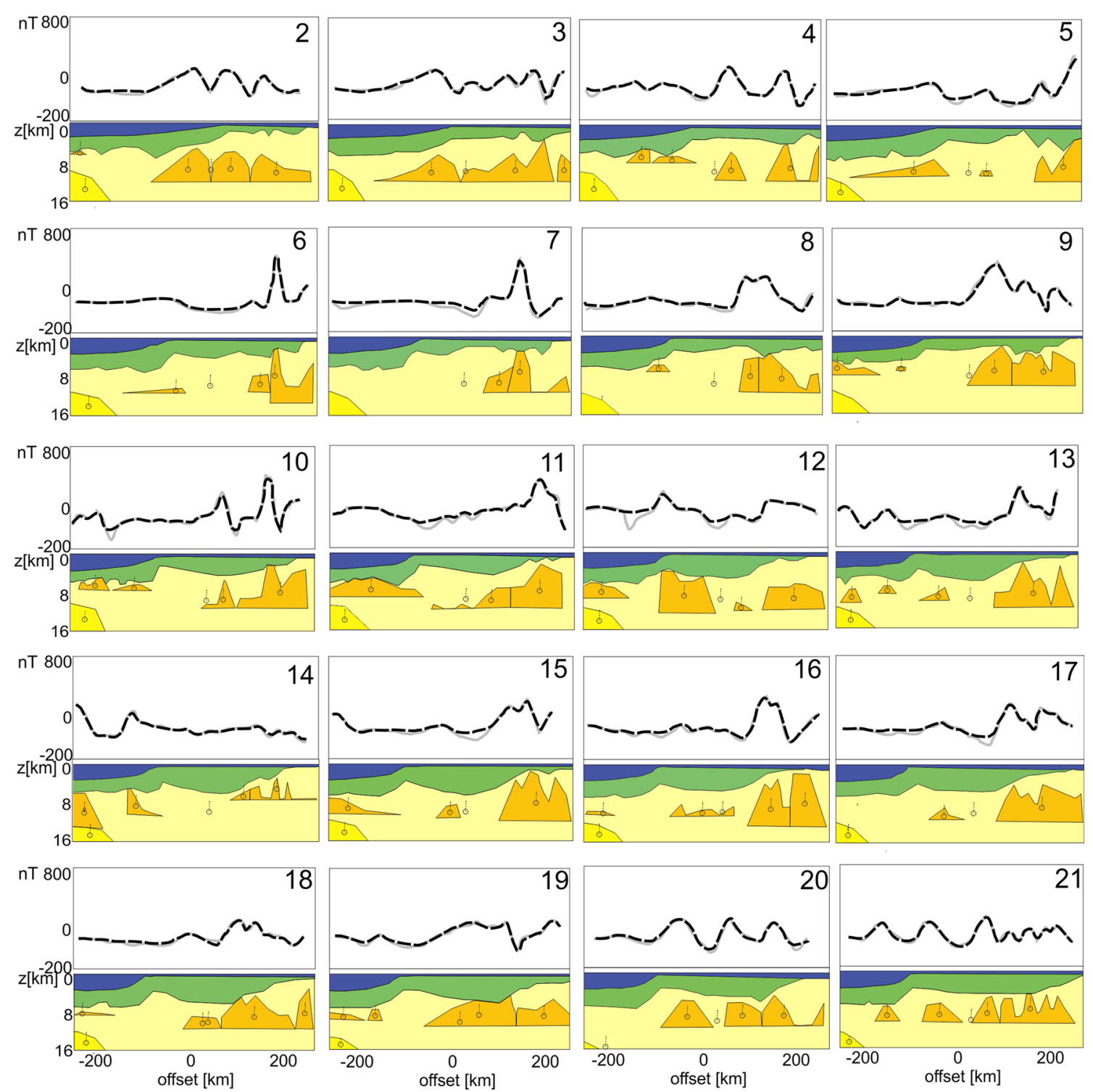

Fig. 12 2-D forward magnetic models of all layers. Database and susceptibility-colour codification is similar to the three example layers in Fig. 11

composition. Thus, the sources of the intrusions are from different fractionation processes of the melt. Mafic intrusions in the eastern embayment can be related to the Dorrel Rock intrusive complex in Marie Byrd Land which is an emplacement of the gabbro from about $34 \mathrm{Ma}$ (Rocchi et al. 2006), implying that a major magmatic event in late Cenozoic affected the Amundsen Sea margin (Kalberg and Gohl 2014).

We attribute the felsic intrusions in the western embayment to decompression melting during WARS-related extension (Gohl et al. 2013a, b), the presence of a mantle plume beneath Marie Byrd Land (e.g. LeMasurier and Landis 1996) or to the large Southwest Pacific Diffuse Alkaline Magmatic Province as postulated by Finn et al.
(2005). For example, Trua et al. (1999) proposed that felsic intrusions can be generated by partial melting of gabbroic material followed by low-pressure fractionation. However, a conclusive process cannot be stated based on our data.

Assuming only a normal lower continental crustal layer in the ASE, the expected density would be around $2800 \mathrm{~kg} /$ $\mathrm{m}^{3}$. This is significant lower than the observed $3150 \mathrm{~kg} / \mathrm{m}^{3}$ (Kalberg and Gohl 2014). The density of this observed layer seems to be also too high for magma of Phanerozoic origin but the occurrence of cumulated layers could significantly rise the density of parts of the crustal material. A similar high-density/high-velocity layer of $10-15 \mathrm{~km}$ thickness was observed beneath normal continental lower crust of the Ethiopian Rift by Mackenzie et al. (2005). 


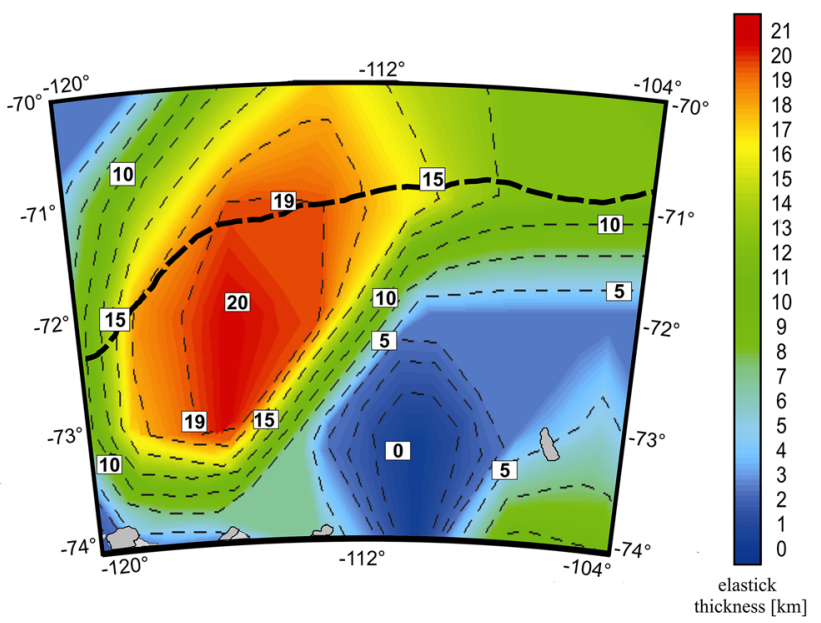

Fig. 13 Map of the effective elastic thickness $\left(\mathrm{T}_{\mathrm{e}}\right)$ of the lithosphere of the Amundsen Sea Embayment. Thick black dashed line marks the shelf break

They interpret a density of about $3170 \mathrm{~kg} / \mathrm{m}^{3}$ as a result of Oligocene underplating of mafic material. We infer a similar process of margin-wide magmatism in the embayment (Kalberg and Gohl. 2014), possibly related to a magmatic insulation flow as part of a lithospheric mantle (Kipf et al. 2014).

\section{$T_{e}$ and rifting}

Our calculated lithospheric elastic thickness $T_{e}$ of $0-5 \mathrm{~km}$ for the eastern Embayment and Pine Island Bay (Fig. 13) correlates with the NNW-SSE trending thick sedimentary basin in the eastern embayment (Fig. 9 and in Gohl et al. 2013b) and with a small positive Bouguer gravity anomaly (Fig. 3b). Unlike the positive Bouguer anomaly associated with sedimentary basins in the Ross Sea Rift, where Te is greater (Karner et al. 2005), it seems unlikely that the Bouguer anomaly could be seen as the consequence of a time lag between mantle uplift during Cretaceous rifting of a weak lithosphere $\left(T_{e}=0 \mathrm{~km}\right)$, followed much later by regionally-compensated Cenozoic sedimentation over a strengthened lithosphere $\left(\mathrm{T}_{\mathrm{e}}=30 \mathrm{~km}\right)$.

Latest gravity inversion results of Cochran et al. (2015) suggest that the ASE shelf has been tectonically inactive since Cretaceous extension and continental breakup. They relate the post-breakup architecture of the embayment and shelf to be the result of subsidence, sedimentation and the advance-retreat cycles of the West Antarctic Ice Sheet. However, our elastic thickness estimates are similar to those over young continental rift zones such as the Basin and Range Province $(\mathrm{Te}=5 \mathrm{~km}$ ) (Lowry and Smith 1994) or the Afar region, followed by the Main Ethiopian Rift ( $\mathrm{Te}=7 \mathrm{~km})$ (Pérez-Gussinyé et al. 2009). We therefore suggest that the low rigidity and the positive Bouguer anomaly of the eastern ASE shelf are signals of fairly recent rift events, possibly related to younger WARS activity (Gohl et al. 2013b) overprinting the Cretaceous extensional phases.

\section{Tectono-magmatic implications}

The lower crust in the ASE with a density that is significantly higher than that of normal lower crust in the region suggests widespread magmatism. This is in agreement with the hypothesis of a continental insulation flow transporting HIMU-like material from beneath western Marie Byrd Land to the Marie Byrd Seamounts at 80-60 Ma (Kipf et al. 2014). Kalberg and Gohl's (2014) schematic tectonomagmatic reconstruction of a 2-D continental rise to shelf gravity model is in agreement with this interpretation (Kalberg and Gohl 2014) which suggests that the continental margin was magmatically underplated. Finn et al. (2005) attributed the Marie Byrd Seamounts to a Southwest Pacific Diffuse Alkaline Magmatic Province, sourced from the mantle over the paleo-Pacific subduction zone that preceded late Cretaceous rifting in the ASE. This part of the mantle is characterised today by low shear velocities (Schaeffer and Lebedev 2013) below Marie Byrd Land, the Ross Sea and the Amundsen Sea.

However, the thickness of the lithosphere, and with it conceivably $T_{e}$, decreases with increasing geothermal gradient that can result from extension or the advection of anomalously warm material (Ebinger et al. 1989; Buck 1991). We observe a decrease in $T_{e}$ at the continental rise of the ASE through the middle shelf of Pine Island Bay which correlates with the slow mantle shear wave velocities (Schaeffer and Lebedev 2013). Similar observations were also made in the East African and Ethiopian rifts (e.g. Pérez-Gussinyé et al. 2009).

The NNE-SSW striking basin in the eastern embayment coincides well with the low $T_{e}$ values (Fig. 13). We suggest that this basin may have developed as a result of transtensional motion on the eastern branch of the WARS. As such, the basin may have a similar origin as the Ferrigno Rift (Bingham et al. 2012) or GVIS (Eagles et al. 2009). If, like in these analogues, the basin lay along part of the West-East Antarctic plate boundary zone and connected with the paleosubduction zone west of Palmer Land and the Antarctic Peninsula, then it would date from some time soon after the $\sim 61 \mathrm{Ma}$ establishment of the East Antarctic-West Antarctic-Phoenix triple junction south of Peter I island.

\section{Conclusions}

Analyses of geophysical data from the ASE provide new insights into the lithospheric architecture and tectonomagmatic development of this part of the continental 
margin of West Antarctica. Our 3-D gravity model supports and expands on previous 2-D velocity-depth and density-depth models (Kalberg and Gohl 2014) and enables an interpretation of the tectono-magmatic history for the Amundsen Sea margin from its breakup with Zealandia to the present, indicating a margin-wide process of magmatic underplating. Our 3-D magnetic model supports earlier interpretations of distinct magmatic events in the embayment. An estimate of the flexural rigidity completes the interpretation of the tectono-magmatic history. The main findings are summarized as follows:

1. 3-D gravity modeling reveals the upper and lower crustal architecture beneath the shelf. The crust is 10-14 km thick at the continental rise, and up to $29 \mathrm{~km}$ thick beneath the inner shelf. A high-density layer of variable thickness, reaching a maximum of $10 \mathrm{~km}$, is ubiquitous at the base of the lower crust. The high-density layer indicates a margin-wide process of magmatic underplating. The crust is intruded by numerous magmatic bodies.

2. 3-D magnetic modelling suggests a set of highsusceptibility bodies that correlate more closely with the modelled magmatic bodies in the eastern embayment than in the western embayment. This suggests magmatic intrusions of more mafic composition in the eastern embayment and material of more felsic composition in the western embayment, and can be interpreted in terms of varying melt sources for the two regions. The mafic intrusions may correlate with the Dorrel Rock intrusive complex in Marie Byrd Land, implying a major magmatic event during the accompanied multi-stage tectonic activity that affected the Amundsen Sea margin during Oligocene. The interpreted felsic intrusions in the western embayment may be attributed to decompression melting during WARS-related extension, to a suspected mantle plume beneath Marie Byrd Land, or to the mantle source of the large Southwest Pacific Diffuse Alkaline Magmatic Province (Finn et al. 2005).

3. Lithospheric rigidity is low (Te of $0-5 \mathrm{~km}$ ) under the Pine Island Bay segment of the eastern Amundsen Sea Embayment and corresponds to a shelf sub-basin observed in seismic records. The low Te supports an interpretation that Cenozoic rifting affected this segment of the Amundsen Sea Embayment.

Acknowledgments We are grateful to the master, crews and scientific teams of the $R V$ Polarstern expeditions ANT-XXIII/4 (2006) und ANT-XXVI/3 (2010) for their support in collecting new geophysical data from the ASE. This project was funded by the Deutsche Forschungsgemeinschaft (DFG) under the DFG Priority Program 'Antarctic Research' with project number GO 724/13-1 and is affiliated with Work Package 3.2 of the AWI research program PACES-II.

\section{References}

Barton P (1986) The relationship between seismic velocity and density of continental crust - a useful constraint? Geophys J R Astron Soc 87:195-208

Behrendt JC, LeMasurier WE, Cooper AK, Tessensohn F, Trefu A, Damaske D (1991) Geophysical studies of the west Antarctic rift arm. Tectonics 10:1257-1273. doi:10.1029/91TC00868

Bell RE, Blankenship DD, Finn CA, Morse DL, Scambos TA, Brozena JM, Hodge SM (1998) Influence of subglacial geology on the onset of a West Antarctic ice stream from aerogeophysical observations. Nature 394(6688):58-62

Bingham RG, Ferracciolo F, King EC, Larter RD, Pritchard HD, Smith AM, Vaughan DG (2012) Inland thinning of West Antarctic Ice Sheet steered along subglacial rifts. Nature 487:468-471. doi:10.1038/nature11292

Bradshaw JD (1991) Cretaceous dispersion of Gondwana: continental and oceanic spreading in the south-west Pacific-Antarctic sector. In: Thomson MRA et al (eds) Geological evolution of Antarctica. Cambridge University Press, Cambridge, pp 581-585

Braitenberg C, Wienecke S, Ebbing J, Born W, Redfield T (2007) Joint gravity and isostatic analysis for basement studies. In: Proceedings of EGM 2007 international workshop, innovation in EM, Grav and Mag methods: a new perspective for exploration, extendend abstracts. Villa Orlandi, Capri, Italy, April 15-18

Buck WR (1991) Modes of continental lithospheric extension. J Geophys Res 96:20161-20178

Cande SC, Stock JM, Müller RD, Ishihara T (2000) Cenozoic motion between East and West Antarctica. Nature 404, 145-150; Palaeoecology 150:247-267

Chaput J, Aster RC, Huerta A, Sun X, Lloyd A, Wiens D, Nyblade A, Anandakrishnan S, Winberry JP, Wilson T (2014) The crustal thickness of West Antarctica. J Geophys Res Solid Earth 119:378-395. doi:10.1002/2013JB010642

Cianciara B, Marcak H (1976) Interpretation of gravity anomalies by means of local power spectra. Geophys Prospect 24:273-286

Cochran JR, Tinto KJ, Bell RE (2015) Abbot Ice Shelf, structure of the Amundsen Sea continental margin and the southern boundary of the Bellingshausen Plate se award of West Antarctica. Geochem Geophys Geosyst. doi:10.1002/2014GC005570

Cooper AH, Stagg H, Geist E (1991) Seismic stratigraphy and structure of Prydz Bay, Antarctica: implications from LEG 119 drilling. In: Proceedings of the ocean drilling program, scientific results, vol 119

Coxall HK, Wilson PA, Palike H, Lear CH, Backman J (2005) Rapid stepwise onset of Antarctic glaciation and deeper calcite compensation in the Pacific Ocean. Nature 433:53-57

Cunningham AP, Larter RD, Barker PF, Gohl K, Nitsche FO (2002) Tectonic evolution of the Pacific margin of Antarctica: 2. Structure of Late Cretaceous - early Tertiary plate boundaries in the Bellingshausen Sea from seismic reflection and gravity data. J Geophys Res 107(B12):2346. doi:10.1029/2002JB001897

Dalziel IWD, Elliot DH (1982) West Antarctica: problem child of Gondwanaland. Tectonics 1:3-19

Davy B, Wood R (1994) Gravity and magnetic modelling of the Hikurangi Plateau. Mar Geol 118:139-151

De Conto R, Pollard D (2003) Rapid Cenozoic glaciation of Antarctica induced by declining atmospheric $\mathrm{CO}_{2}$. Nature 421:245-249

Denk A (2011) Analysis of ship-borne and helicopter-borne magnetic data in the Amundsen Sea, West Antarctica. Diploma Thesis, Universität Köln

Domack EW, Ishman S (1992) Magnetic susceptibility of Antarctic glacial marine sediments. Antarct J Unit States 27(5):64 
Dorman LM, Lewis BTR (1970) Experimental isostasy: 1. Theory of the determination of the earth's isostatic response to a concentrated load. J Geophys Res 75:3357-3365

Eagles G, Jokat W (2014) Tectonic reconstructions for paleobathymetry in Drake Passage. Tectonophysics 611:28-50. doi:10.1016/j.tecto.2013.11.021

Eagles G, Gohl K, Larter RD (2004a) High-resolution animated tectonic reconstruction of the South Pacific and West Antarctic margin. Geochem Geophy Geosyst. doi:10.1029/2003GC000657

Eagles G, Gohl K, Larter RD (2004b) Life of the Bellingshausen plate. Geophys Res Lett 31. doi:10.1029/2003GL019127

Eagles G, Larter RD, Gohl K, Vaughan APM (2009) West Antarctic Rift System in the Antarctic Peninsula. Geophys Res Lett 36:L21305. doi:10.1029/2009GL040721

Ebinger CJ, Deino AL, Drake RE, Tesna AL (1989) Chronology of volcanism and rift basin propagation: rungwe volcanic province, East Africa. J Geogr Res 94:15785-157803

Finn CA, Müller RD, Panter KS (2005) A Cenozoic diffuse alkaline magmatic province (DAMP) in the southwest Pacific without rift or plume origin. Geochem Geophys Geosyst 6:Q02005. doi:10. 1029/2004GC000723

Fretwell P, Pritchard HD, Vaughan DG, Bamber JL, Barrand NE, Bell $\mathrm{R}$, Bianchi C, Bingham RG, Blankenship DD, Casassa G, Catania G, Callens D, Conway H, Cook AJ, Corr HFJ, Damaske D, Damm V, Ferraccioli F, Forsberg R, Fujita S, Gogineni P, Griggs JA, Hindmarsh RCA, Holmlund P, Holt JW, Jacobel RW, Jenkins A, Jokat W, Jordan T, King EC, Kohler J, Krabill W, Riger-Kusk M, Langley KA, Leitchenkov G, Leuschen C, Luyendyk BP, Matsuoka K, Nogi Y, Nost OA, Popov SV, Rignot E, Rippin DM, Riviera A, Roberts J, Ross N, Siegert MJ, Smith AM, Steinhage D, Studinger M, Sun B, Tinto BK, Welch BC, Young DA, Xiangbin C, Zirizzotti A (2013) Bedmap2: improved ice bed, surface and thickness datasets for Antarctica. Cryosphere Discuss 6:4305-4361

Gohl K (2012) Basement control on past ice sheet dynamics in the Amundsen Sea Embayment, West Antarctica. Palaeogeogr Palaeoclimatol Palaeoecol 335-336:35-41. doi:10.1016/j. palaeo.2011.02.022

Gohl K, Teterin D, Eagles G, Netzeband G, Grobys J, Parsiegla N, Schlüter P, Leinweber V, Larter RD, Uenzelmann-Neben G, Udintsev GB (2007) Geophysical survey reveals tectonic structures in the Amundsen Sea Embayment, West Antarctica. In: Cooper AK, Raymond CR, et al. (eds) Proceedings of the 10th international symposium of Antarctic earth sciences. USGS Open-File Report 2007-1047. doi:10.3133/of2007-1047.srp047

Gohl K, Denk A, Eagles G, Wobbe F (2013a) Deciphering tectonic phases of the Amundsen Sea Embayment shelf, West Antarctica, from a magnetic anomaly grid. Tectonophysics 585:113-123. doi:10.1016/j.tecto.2012.06.036

Gohl K, Uenzelmann-Neben G, Larter RD, Hillenbrand C-D, Hochmuth K, Kalberg T, Weigelt E, Davy B, Kuhn G, Nitsche F-O (2013b) Seismic stratigraphic record of the Amundsen Sea Embayment shelf from pre-glacial to recent times: evidence for a dynamic West Antarctic Ice Sheet. Mar Geol 344(115-131): 2013. doi:10.1016/j.margeo.2013.06.011

Götze HJ, Lahmeyer B (1988) Application of three-dimensional interactive modeling. In: Gravity and magnetics, Geophysics 53(8):1096-1108

Granot R, Cande SC, Stock JM, Damaske D (2013) Revised EoceneOligocene kinematics for the West Antarctic Rift System. Geophys Res Lett 40:279-284. doi:10.1029/2012GL054181

Grobys JWG, Gohl K, Eagles G (2008) Quantitative tectonic reconstructions of Zealandia based on crustal thickness estimates. Geochem Geophy Geosyst 9(1):Q01005. doi:10.1029/ 2007GC001691
Grunow AM, Kent DV, Dalziel IWD (1991) New paleomagnetic data from Thurston Island: Implications for the tectonics of West Antarctica and Weddell Sea opening. J Geophys Res 96:17935-17954

Hay WW (1996) Tectonics and Climate. Geol Rundsch 85:409-437

Hochmuth K, Gohl K (2013) Glaciomarine sedimentation dynamics of the Abbot glacial trough of the Amundsen Sea Embayment shelf, West Antarctica. In: Hambrey MJ, Barker PF, Barrett PJ, Bowman V, Davies B, Smellie JL, Tranter M (eds) In: Antarctic palaeoenvironments and earth-surface processes, vol 381. Geological Society, Special Publications, London

Jordan TA, Ferraccioli F, Vaughan DG, Holt JW, Corr H, Blankenship DD, Diehl TM (2010) Aerogravity evidence for major crustal thinning under the Pine Island Glacier region (West Antarctica). Geol Soc Am Bull 122:714-726. doi:10.1130/ B26417.1

Kalberg T, Gohl K (2014) The crustal structure and tectonic development of the continental margin of the Amundsen Sea Embayment, West Antarctica: implications from geophysical data. Geophys J Int 198(1):327-341

Karner GD, Watts AB (1983) Gravity anomalies and flexure of the lithosphere at mountain ranges. J Geophys Res 88:10449-10477

Karner GD, Studinger M, Bell R (2005) Gravity anomalies of sedimentary basins and their mechanical implications: application to the Ross Sea basins, West Antarctica. Earth Planet Sci Lett 235:577-596

Kipf A, Hauff F, Werner R, Gohl K, van den Bogaard P, Hoernle K, Maicher D, Klügel A (2014) Seamounts off the West Antarctic margin: a case of non-hotspot intraplate volcanism. Gondwana Res 25:1660-1679. doi:10.1016/j.gr.2013.06.013

Larter RD, Cunningham AP, Barker PF, Gohl K, Nitsche FO (2002) Tectonic evolution of the Pacific margin of Antarctica 1. Late Cretaceous tectonic reconstructions. J Geophys Res 107(B12): 2345

Lawver LA, Gahagan LM, Dalziel IWD (2011) A different look at gateways: Drake passage and Australia/Antarctica. In: Anderson JB, Wellner JS (eds) Tectonic, climatic, and cryospheric evolution of the Antarctic Peninsula, Special Publication No. 063, American Geophysical Union, p 5-33. doi: 10.1029/ 2010SP001017

LeMasurier WE (2008) Neogene extension and basin deepening in the West Antarctic rift inferred from comparisons with the East African rift and other analogs. Geology 36:247-250. doi:10. 1130/G24363A.1

LeMasurier WE, Landis CA (1996) Mantle-Plume, activity recorded by low relief erosion surfaces in West Antarctica and New Zealand. Geol Soc Am Bull 108:1450-1466

Lindow J, Spiegel C, Johnson J, Lisker F, Gohl K (2011) Constraining the latest stage exhumation of Marie Byrd and Ellsworth Land, West Antarctica. In: 11th international symposium on Antarctic earth science, Edinburgh, Scotland

Lowry AR, Smith RB (1994) Flexural rigidity of the Basin and Range-Colorado Plateau-Rocky Mountain transition from coherence analysis of gravity and topography. J Geophys Res 99:20123-20140

Luyendyk BP, Sorlien CC, Wilson DS, Bartek LR, Siddoway CH (2001) Structural and tectonic evolution of the Ross Sea rift in the Cape Colbeck region, Eastern Ross Sea, Antarctica. Tectonics 20:933-959

Luyendyk B, Wilson DS, Siddoway CS (2003) Eastern margin of the Ross Sea Rift in western Marie Byrd Land, Antarctic: crustal structure and tectonic development. Geochem Geophys Geosyst. doi:10.1029/2002GC000462

Mackenzie GD, Thybo H, Maguire PKH (2005) Crustal velocity structure across the Main Ethiopian Rift: results from two- 
dimensional wide-angle seismic modelling. Geophys J 162(3):994-1006

Maus S, Macmillan S, McLean S, Hamilton B, Thomson B, Nair M, Rollins C (2010) The US/UK world magnetic model for 2010-2015, NOAA Technical Report NESDIS/NGDC

Mayes CL, Lawver LA, Sandwell DT (1990) Tectonic history and new isochron chart of the South Pacific. J Geophys Res 95:8543-8567

McAdoo DC, Laxon S (1999) Antarctic tectonics: constraints from an ERS-1 satellite marine gravity field. Science $276: 556-560$

Mortimer et al (2006) New constraints on the age and evolution of the Wishbone Ridge, southwest Pacific Cretaceous microplates, and Zealandia-West Antarctica breakup. Geology 34(3):185-188. doi:10.1130/G22168.1

Müller RD, Gohl K, Cande SC, Goncharov A, Golynsky AV (2007) Eocene to Miocene geometry of the West Antarctic Rift System. Aust J Earth Sci 54:1033-1045. doi:10.1080/081200907016 15691

Nitsche FO, Jacobs SS, Larter RD, Gohl K (2007) Bathymetry of the Amundsen Sea continental shelf: implications for geology, oceanography, and glaciology. Geochem Geophys Geosyst. doi:10.1029/2007GC001694

Pérez-Gussinyé M, Metois M, Fernández M, Vergés J, Fullea J, Lowry A (2009) Effective elastic thickness of Africa and its relationship to other proxies for lithospheric structure and surface tectonics. Earth Planet Sci Lett 287(1-2):152-167

Rocchi S, LeMasurier WE, Di Vincenzo G (2006) Oligocene to Holocene erosion and glacial history in MBL, West Antarctica, inferred from exhumation of the Dorrel Rock intrusive complex and from volcano morphologies. Geol Soc Am Bull 118:991-1005

Sanger EA, Glen JMG (2003) Density and magnetic susceptibility values for rocks in the Talkeetna Mountains and adjacent region, South-Central Alaska. U.S. Geological Survey Open-File Report $03-268$

Schaeffer AJ, Lebedev S (2013) Global shear-speed structure of the upper mantle and transition zone. J. Int, Geophys. doi:10.1093/ gji/ggt095

Shapiro NM, Ritzwoller MH (2004) Inferring surface heat flux distributions guided by a global seismic model: particular application to Antarctica, Earth Planet. Sci. Lett. 223:213-224

Spector A, Grant FS (1970) Statistical models for interpreting aeromagnetic data. Geophysics 35:293-302

Sterritt VA (2006) Understanding physical property: mineralogy relationships in the context of geologic processes in the ultramafic rock-hosted mineral deposit environment : aiding interpretation of geophysical data. Retrospective Theses and Dissertations, 1919-2007, Earth and Ocean Sciences Theses and Dissertations

Storey BC (1991) The crustal blocks of West Antarctica within Gondwana: reconstruction and break-up model. In: Thomson
MRA, Crane JA, Thomson JW (eds) Geological evolution of Antarctica. Cambridge University Press, Cambridge

Studinger MS (2001) Interpretation und Analyse von Potentialfelddaten im Weddellmeer, Antarktis: der Zerfall des Superkontinents Gondwana. Dissertation. University of Bremen

Syberg FJR (1972) A Fourier method for the regional-residual problem of potential fields. Geophys Prospect 20:47-75

Tessensohn F, Wörner G (1991) The Ross Sea rift system (Antarctica). Structure, evolution and analogues. In: Thompson MRA, Crame JA, Thomson JW (eds) Geological evolution of Antarctica. Cambridge University Press, Cambridge, pp 273-277

Trey H, Cooper AK, Pellis G, Della Vedova B, Cochrane G, Brancolini G, Makris J (1999) Transect across the West Antarctic Rift System in the Ross Sea, Antarctica. Tectonophysics 301:61-74

Trua T, Deniel C, Mazzuoli R (1999) Crustal control in the genesis of Plio-Quaternary bimodal magmatism of the Main Ethiopian Rift (MER), geochemical and isotopoic ( $\mathrm{SR}, \mathrm{ND}, \mathrm{Pb}$ ) evidence. Chem Geol 155:201-231

Uenzelmann-Neben G, Gohl K (2012) Amundsen Sea sediment drifts: archives of modifications in oceanographic and climatic conditions. Mar Geol 299-302:51-62. doi:10.1016/j.margeo.2011.12. 007

Uenzelmann-Neben G, Gohl K (2014) Early glaciation already during the Early Miocene in the Amundsen Sea, Southern Pacific: indications from the distribution of sedimentary sequences. Global Planet Change 120:92-104. doi:10.1016/j.gloplacha. 2014.06.004

Uenzelmann-Neben G, Gohl K, Larter RD, Schlüter P (2007) Differences in ice retreat across Pine Island Bay, West Antarctica, since the Last Glacial Maximum: Indications from multichannel seismic reflection data. In: Cooper AK, Raymond CR, et al. Proceedings of the 10th ISAES. USGS Open-File Report 2007-1047. doi:10.3133/of2007-1047.srp084

Watts AB (2001) Isostasy and flexure of the lithosphere. Cambridge University Press, Cambridge, $\mathrm{p} 458$

Weigelt E, Gohl K, Uenzelmann-Neben G, Larter RD (2009) Late Cenozoic ice sheet cyclicity in the western Amundsen Sea Embayment-evidence from seismic records. Global Planet Change 69:162-169

Winberry JP, Anandakrishnan S (2004) Crustal structure of the West Antarctic Rift System and Marie Byrd Land hotspot. Geology 32(11):977-980. doi:10.1130/G20768.1

Wobbe F, Gohl K, Chambord A, Sutherland R (2012) Structure and breakup history of the rifted margin of West Antarctica in relation to Cretaceous separation from Zealandia and Bellingshausen plate motion. Geochem Geophys Geosyst 13:Q04W 12 . doi:10.1029/2011GC003742 